\title{
Working
}

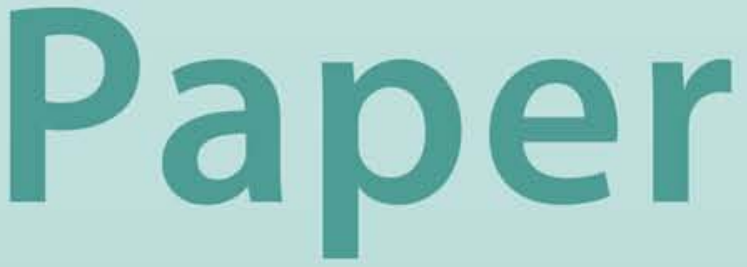


The Fear of Freedom: Politicians and the Independence and Accountability of Financial Sector Supervisors

Marc Quintyn, Silvia Ramirez, and Michael W. Taylor 


\title{
IMF Working Paper
}

Monetary and Capital Markets Department

\section{The Fear of Freedom: Politicians and the Independence and Accountability of Financial Sector Supervisors}

\author{
Prepared by Marc Quintyn, Silvia Ramirez, and Michael W. Taylor ${ }^{1}$ \\ Authorized for distribution by Charles Enoch
}

February 2007

\begin{abstract}
This Working Paper should not be reported as representing the views of the IMF. The views expressed in this Working Paper are those of the author(s) and do not necessarily represent those of the IMF or IMF policy. Working Papers describe research in progress by the author(s) and are published to elicit comments and to further debate.

Compared with the case of central bank independence, independence for financial sector supervisors remains more controversial. This paper analyzes changes in independence and accountability arrangements in a set of 32 countries that overhauled their legal and/or institutional frameworks for supervision in recent years. Despite improvements, there is strong evidence that the endorsement of independence remains half-hearted, which shows itself through either overcompensation on the accountability side, or resort to political control mechanisms. The latter could potentially undermine the agency's credibility. The results indicate that policymakers still need to be persuaded of the long-term benefits of independence for financial sector soundness, and of the potential for a virtuous interaction between independence and accountability, if the arrangements are well-designed.
\end{abstract}

JEL Classification Numbers: G21, G28, H83, L51

Keywords: Bank supervision, financial regulation, agency independence, public administration accountability

Author's E-Mail Address: $\quad$ mquintyn@,imf.org; sramirez@,imf.org; michael taylor@hkma.hk.gov

\footnotetext{
${ }^{1}$ Michael Taylor is Head, Banking Policy, Hong Kong Monetary Authority. Earlier versions of this paper were presented at the conference on "Designing Financial Supervision Institutions: Independence, Accountability, and Governance," at Bocconi University, Milan, May 29-30, 2006 and at an IMF/MCM seminar on October 12, 2006. The authors would like to thank, without implication, Jonathan Westrup (discussant at the conference), Jacob de Haan, Donato Masciandario, and Tonny Lybek for valuable comments and suggestions, as well as the participants at both presentations. "The Fear of Freedom" is the title of a 1942 book by Erich Fromm.
} 
I. Introduction and Overview

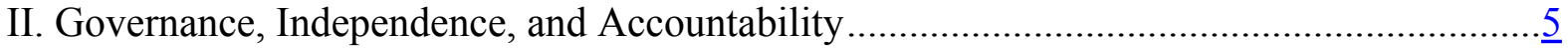

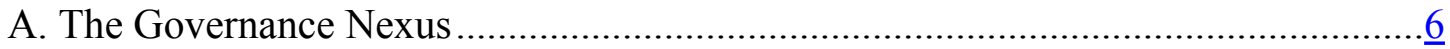

B. Four Pillars of Regulatory Governance..............................................................

III. Independence and Accountability in Practice.........................................................

A. The Four Dimensions of Independence ....................................................

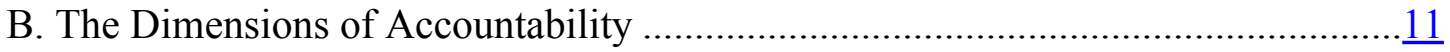

IV. What Are the Emerging Trends? .................................................................. 15

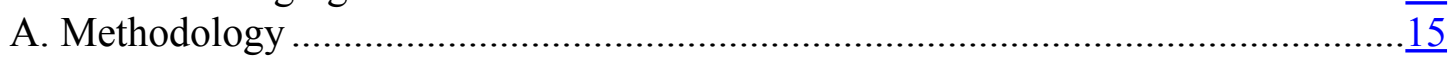

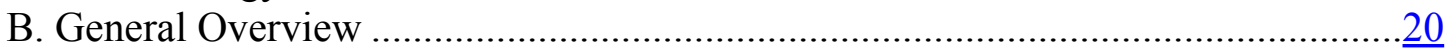

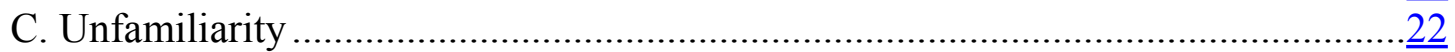

D. Fear of Freedom: What Worries Governments the Most? ...................................23

E. A Closer Look at Individual Countries ........................................................... $\frac{27}{30}$

F. Additional Perspectives ...................................................................

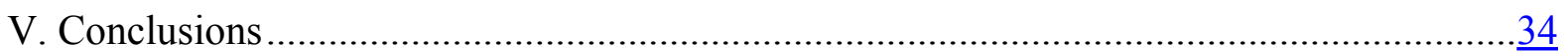

Tables

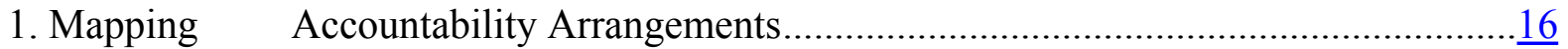

2. Independence and Accountability Overview ..................................................... $\frac{21}{22}$

3. Overview of Changes in the Ratings ............................................................

4. Changes in Meeting Specific Independence and Accountability Criteria ..................26

5. Accountability and Independence: Regional Trends .........................................

6. Accountability and Independence: Trends by Country Income Levels .......................

7. Accountability and Independence: Trends by Location of Institution.........................

8. Accountability and Independence: Trends by Type of Change................................ $\frac{33}{34}$

9. Accountability and Independence: Trends by Immediate Cause of Reform ................34

Figures

1. Ratings Results for Selected Countries ......................................................

Appendixes

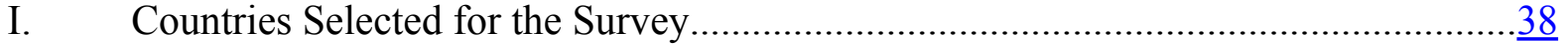

II. Criteria for the Index on Independence and Accountability for Financial Sector

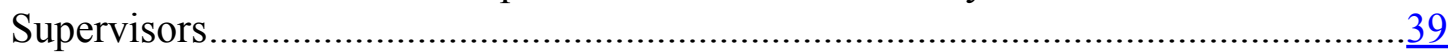

III. Scatter Plot of Ratings Before and After ........................................................ $\frac{42}{43}$

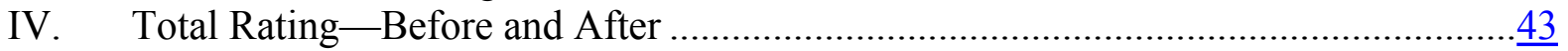

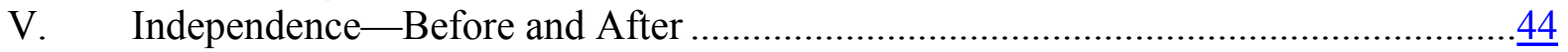

VI. Accountability -Before and After.............................................................. 45

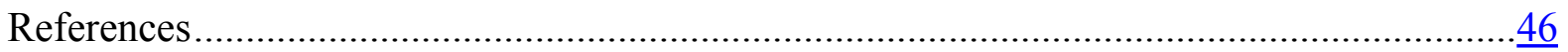




\section{INTRODUCTION AND OVERVIEW}

The discussion about independence, accountability and, more broadly, governance of financial sector regulatory and supervisory agencies (hereafter RSA) is still relatively new. Lastra (1996) and Goodhart (1998) were among the first scholars to stress the need for RSA independence. ${ }^{2}$ The Basel Core Principles for Effective Banking Supervision (1997) put the need for operational independence for bank supervisors in the first principle, and, as such, provided the need for independence with a more "official" endorsement. ${ }^{3}$

The operational aspects of RSA independence only began to receive sustained attention in the new millennium. Quintyn and Taylor (2003) defined four essential dimensions of RSA independence - regulatory, institutional, supervisory, and budgetary. Hüpkes, Quintyn, and Taylor (2005b) subsequently emphasized that (i) proper accountability arrangements are needed to make agency independence effective; and (ii) a complex undertaking, such as financial sector supervision, needs an elaborate set of accountability arrangementsarguably, more elaborate than the arrangements in place for the central banks when executing their monetary policy functions. Accordingly, their paper presented a range of accountability arrangements suitable to meet these requirements.

The policymakers' interest in questions of independence and accountability for supervisors has been stimulated by the emergence of a much broader debate about the institutional structure of financial regulation that began in the early-to-mid-1990s. Previously, the organizational structure of supervision had been widely viewed as a relatively unimportant issue, both in theory and in practice, but this perception changed dramatically about a decade ago. ${ }^{4}$ The new wave of attention was the result of a variety of developments, which themselves followed in the wake of financial liberalization. First, the blurring of boundaries among financial subsectors, and the emergence of financial conglomerates - mainly in industrialized countries - forced the supervisors to rethink their organizational structure in order to be in a position to effectively supervise these new realities. Second, the emergence of international standards and codes for a wide range of financial sector supervisors instigated a rethinking of regulatory and supervisory frameworks, often with an impact on the organizational structure. Third, the systemic banking crises of the 1990s also led to revisions of institutional structures. It was indeed clear that in several cases, weak regulation and supervision - often because of intense political interference- - had been a contributing factor to the crises.

\footnotetext{
${ }^{2}$ In her account of the Venezuelan banking crisis in 1994, Ruth de Krivoy also mentions the need for political independence for the supervisors as one of the main lessons (de Krivoy, 2000).

${ }^{3}$ The Basel Core Principles for Effective Banking Supervision have since been followed by the other standard setters. The IOSCO and IAIS principles now also state explicitly the requirement for operational independence for securities regulators and insurance supervisors.

${ }^{4}$ Goodhart (2002).
} 
In particular, the growing tendency to move to unified (or integrated) financial sector supervisors (often called mega-supervisors) was instrumental in stimulating the debate about the appropriate governance structure of these agencies, starting with agency independence. Unification often involved transferring the banking supervisory function to an agency outside the central bank, where it had previously enjoyed a relatively high degree of independence. In several countries, this led to concerns that removing banking supervision from the central bank would create a less-independent function than existed previously. This fear was further stimulated when investigation of existing sector-specific regulatory agencies revealed greatly varying levels of independence among them and led to concerns that the independence of the newly established agency might be set according to the lowest common denominator.

The purpose of this paper, a primer in this genre, is to analyze to what extent the debate about greater independence-cum-accountability for financial sector supervisors is finding its way into practical implementation. The central themes of the analysis are (i) whether the restructured supervisors are more independent than their predecessors, and (ii) whether accountability arrangements have been created in such a way that they support independence? While pursuing these main questions, the paper also tries to answer questions such as (i) which aspects of independence and which accountability arrangements are easy to accept, and for which ones do we find reluctance on the part of the politicians; and (ii) which circumstances and types of restructuring lead to more far-reaching reforms in independence and accountability than others.

To achieve these objectives, the paper considers a set of 32 countries that, in the past decadeand-half, went through either institutional changes in the supervisory structure (evidently, accompanied by changes in the legal framework), or through in-depth changes in the legislative framework governing financial sector supervision, without changing the institutional structure for supervision. The focus is on bank supervision.

In the end, the message from this analysis is rather mixed. On the one hand, the paper notes a number of positive trends. The survey reveals that governments seem willing to provide more independence to supervisors, and they also appear to place greater emphasis on accountability now than in the past. Accountability arrangements are stronger and more diversified than before. In many ways, the increased emphasis being given to accountability arrangements is in compensation for the fact that they were generally weak before the reforms.

On the other hand, once the analysis goes past these general trends, the message becomes much more nuanced. From a more detailed analysis of the results and confrontation with other sources of research, it appears that the endorsement of independence remains half-hearted, and that a fair portion of the improvements in accountability can be put down to residual reluctance to see genuinely independent agencies. Many governments still seem to entertain the trade-off model between independence and accountability (as opposed to the complementarity model), and their revealed preference is for more accountability rather than for more independence. 
Significant in this regard is the finding that a large number of country authorities in the survey continue to use control mechanisms as accountability arrangements ${ }^{5}$ - such as having the minister of finance or a finance ministry representative, chair or participate in the board of the supervisory agency, or giving the minister the right to intervene in the operations of the agency. In other words, the (fine) line between accountability and control is either not always well understood, ${ }^{6}$ or the existence of these control mechanisms may indicate that the political class is not yet ready to provide full independence to RSAs. "Control" arrangements tend to undermine the credibility of independence arrangements and make some of the genuine accountability arrangements less relevant.

For reasons explored in Quintyn and Taylor (2003), there appears to be greater reluctance on the part of politicians to grant independence to regulatory agencies compared with the monetary policy functions of central banks, notwithstanding the fact that the fundamental justification for both types of independence is very similar. Thus, although this paper reveals encouraging trends, it also points to the need for making the case for the benefits of supervisory independence for financial stability more vigorously. The case also needs to be more strongly put that accountability arrangements are needed to bolster this independence, not to rein in the supervisors' work. Given that the survey only covers a limited number of countries that have been fairly recent reformers, it is likely that there is still a great deal of work to be done in the rest of the world.

The paper is structured as follows. Section II puts independence and accountability in the broader governance framework. Section III outlines the main operational components of agency independence and accountability. As such, it will set the stage for Section IV, which surveys developments in a number of countries that went through changes in their supervisory structure in the past decade. Section V brings together the most important conclusions of the paper.

\section{GOVERNANCE, INDEPENDENCE, AND ACCOUNTABILITY}

The need for good regulatory governance in the context of financial sector policymaking and crisis prevention has begun to be recognized in recent years. It is increasingly being acknowledged that a financial system is only as strong as its governing practices, the soundness of its institutions, and the efficiency of its market infrastructure. This section briefly reviews the importance of regulatory governance, as well as its four pillars.

\footnotetext{
5 The distinction between accountability and control is discussed in detail in Hüpkes, Quintyn, and Taylor (2005a) and (2005b).

${ }^{6}$ This finding may indeed also be related to the inherent complexity of accountability arrangements, and to the relative unfamiliarity of the idea that independence and accountability are there to reinforce each other.
} 


\section{A. The Governance Nexus}

Instilling and using sound governance practices is a shared responsibility of market participants and regulatory agencies. ${ }^{7}$ The three components of this shared responsibility were presented in Das and Quintyn (2002) and Das, Quintyn, and Chenard (2004) as the "governance nexus." The governance nexus refers to the impact of governance practices on each layer-government, supervisors, and financial institutions - on practices on the next layer. From bottom to top, we have the following three components and their responsibilities:

- $\quad$ First, financial institutions bear the ultimate responsibility for establishing good governance practices internally in order to gain and keep the confidence of their clients, counterparties, and the markets. Their good practices are supposed to stimulate good practices with their borrowers.

- $\quad$ Second, regulatory agencies play a key role in instilling and overseeing implementation of the use of such good practices. To fulfill this role, regulatory agencies themselves need to establish and operate sound governance practices. By failing to apply good governance principles, regulatory agencies would lose the credibility and moral authority to promulgate good practices in the institutions under their oversight. This could create a moral hazard problem, contribute to unsound practices in the markets, and, ultimately, accentuate crises in the financial system.

- $\quad$ Third, good regulatory governance cannot be sustained without good public sector governance. The latter includes the absence of corruption, a sound approach to competition policies, effective legal and judicial systems, and an arm's-length approach to government ownership.

\section{B. Four Pillars of Regulatory Governance}

A prerequisite for good regulatory governance - the second link in the nexus above - is firm institutional underpinnings for RSA. Das and Quintyn (2002) identified four components that bring together the elements that form the basis for good regulatory governance:

independence, accountability, transparency, and integrity. ${ }^{8}$ The essence of bringing together these four components is that they interact and reinforce each other at various levels in supporting good governance. Independence and accountability are two sides of the same coin. Independence cannot be effective without proper accountability. Transparency is a key instrument to make accountability work. It is also a vehicle for safeguarding independence. By making actions and decisions transparent, chances for interference are reduced.

\footnotetext{
${ }^{7}$ A growing body of empirical literature demonstrates the positive impact of good regulatory governance on financial sector stability and growth. Barth, Caprio, and Levine (2001) show a positive relationship between supervisory independence and bank development. Das, Quintyn, and Chenard (2004) demonstrate that regulatory governance positively influences financial sector stability. Arnone, Darbar, and Gambini (forthcoming) find a positive relationship between good governance and the quality of financial regulation and supervision.

${ }^{8}$ See Das and Quintyn (2002) and Das, Quintyn, and Chenard (2004) for a discussion of these four pillars.
} 
Transparency also helps to establish and safeguard integrity in the sense that published arrangements provide even better protection for agency staff. Independence and integrity also reinforce each other. Legal protection of agency staff, as well as clear rules for appointment and removal of agency heads, support both their independence and their integrity. Finally, accountability and integrity also reinforce each other. Because of accountability requirements, there are additional reasons for heads and staff to keep their integrity.

This paper focuses on recent developments in independence and accountability. The main reason for singling out this pair is that among the four components, they seem the hardest to achieve. Establishment of proper independence and accountability arrangements needs endorsement by the politicians in the enabling legislation. A lingering fear for independence, combined with a lack of understanding of the working of accountability (both noted in this paper), makes their establishment very often a big hurdle. ${ }^{9}$ Once independence and accountability have been established by law, the agency itself is in an ideal position to make the other two components - transparency and integrity arrangements - operational. These components are more a matter of internal arrangements to support the two others in establishing good governance practices.

\section{INDEPENDENCE AND ACCOUNTABILITy IN PRACTICE}

Combining the earlier work in Quintyn and Taylor (2003) and Hüpkes, Quintyn, and Taylor (2005b), this section outlines the main components of independence and accountability in practice. The survey in the next section builds upon the framework established here.

\section{A. The Four Dimensions of Independence}

It is useful as a first step to distinguish between goal independence and instrument independence (Fischer, 1994). This distinction enables us to separate the overall objective that the regulatory agency is required to achieve, and which is established in the law creating the agency, from the actual formulation and implementation of supervisory and regulatory policies ("instrument independence"), which can be left safely to the judgment of specialist officials. Hence, politicians have a proper role to play in setting and defining regulatory and supervisory goals, but regulators need to have the autonomy to determine how they should achieve them - and to also be accountable in the event that they fail to achieve them.

\footnotetext{
${ }^{9}$ Empirical evidence supports the view that independence and accountability are harder to implement than the two other pillars. IMF and World Bank (2002), and Arnone, Darbar, and Gambini (forthcoming), both find that the Basel Core Principle 1.2. concerning operational independence is one with the lowest number of fully compliant assessments (31 countries out of 116 in Arnone, Darbar, and Gambini, forthcoming). In addition, in their analysis of the IMF Transparency Code for Bank Supervisors, Arnone, Darbar, and Gambini (forthcoming) find that observance of Practice 8 on transparency of accountability arrangements is lower than observance of the other practices. Although this code is, in the first place, about transparency of practices, the lack of transparency often shows the absence of the practice, supporting the point that is made in this paper.
} 
To make the notion of instrument independence operational, we identify four different dimensions - institutional, regulatory, supervisory, and budgetary independence. The regulatory and supervisory dimensions form the core, while institutional and budgetary independence are essential to support the execution of the core functions.

\section{Institutional independence}

Institutional independence refers to the status of the agency as an institution separate from the executive and legislative branches of government. An agency that forms part of the executive branch, such as the ministry of finance, typically lacks independence. The following are three critical elements of institutional independence:

- The terms of appointment and — even more critically—dismissal of its senior personnel. Independence is best served if there are clear rules on hiring and firing, which should primarily relate to regulators' competence and probity. Under such rules, regulators would enjoy security of tenure, enabling them to speak and take action without fear of dismissal by the government of the day. Ideally, both the executive and legislative branches of government should be involved in the appointment process.

- The agency's governance structure. Multi-member commissions help ensure consistency and continuity of decision-making over time and are less likely to be influenced by the views of any one individual.

- The openness and transparency of decision making. Inevitably, many decisions involve commercially sensitive material that would be difficult to disclose. But the presumption should be in favor of openness in the decision-making process, making it possible for both the public and the industry to scrutinize regulatory decisions, minimizing the risk of political interference.

\section{Regulatory independence}

Regulatory independence refers to the ability of the agency to have an appropriate degree of autonomy in setting prudential rules and regulations for the sectors under its supervision, within the confines of the law. ${ }^{10}$ Prudential regulations cover general rules on the stability of the business and its activities (legally required minimum amount of capital, and fit and proper requirements for senior management), as well as specific rules that follow from the special nature of financial intermediation (risk-based capital ratios, limits on off-balance sheet activities, definition of limits on exposure to a single borrower, limits on connected lending, foreign-exposure limits, loan-classification rules, and loan-provisioning rules).

\footnotetext{
${ }^{10}$ Prudential rules differ from two other categories of regulations that govern banking: economic regulations, encompassing controls over pricing, profits, entry, and exit; and information regulations, governing the information that needs to be provided to the public at large and to the supervisors. These two types of rules tend not to be subject to frequent amendations and could, therefore, be left to the lawmakers following a consultation process with the supervisors.
} 
These are the fundamental rules upon which the supervisory process rests and which have a large impact on the soundness of the banking system. From the point of view of regulatory independence, a high degree of autonomy in setting prudential regulations is a key requirement to ensure that the sector complies with international best standards and practices. A lack of autonomy in this area introduces the risk that precious time might be lost (typically up to one year and sometimes longer) before new rules or regulations are adopted in the political process, or that involvement of the political process contaminates these rather technical rules with political considerations. ${ }^{11}$

For those countries where the constitution or legal traditions do not allow independent agencies to have regulatory powers, consideration should be given to whether exceptions can be granted based on the importance of the financial sector regulatory and supervisory function, as has been done in some countries with respect to the central bank. ${ }^{12}$

\section{Supervisory independence}

Supervisory independence concerns the independence with which the agency is able to exercise its judgment and powers in such matters as licensing, on-site inspections and off-site monitoring, sanctioning, and enforcement of sanctions (including revoking licenses), which are the supervisors' main tools to ensure the stability of the system.

While supervisory independence is crucial for financial sector stability, it is the most difficult of the four dimensions of independence to guarantee. To preserve its effectiveness, the supervisory function typically involves private ordering between the supervisor and the supervised institution. But the privacy of the supervisory process makes it vulnerable to interference, both from politicians and supervised entities. Political interference (and interference from the industry itself) can take many forms and can indeed be very subtle, making it difficult to shield the supervisors from all forms of interference.

Since "Licensing is the key first step in the supervisory process" (Lastra, 1996), supervisors should have the final word on who can enter the system. A typical situation that may lead to problems is one where the minister of finance or the council of ministers has the final say in the licensing of individual banks and may - either through corruption or lack of technical ability to assess business plans - license unviable banks. The same degree of autonomy should apply to exit procedures, based on the same argument that supervisors are in the best position to decide on the viability of individual banks. Exit decisions that are taken on political rather than technical grounds may result in forbearance and the prolongation of the life of insolvent or corrupt institutions, thus, ultimately increasing resolution costs.

\footnotetext{
${ }^{11}$ For example, in some countries the authorities have lowered loan-classification standards and provisioning rules for loans to economic sectors that face temporary or structural problems, in order to facilitate lending to these sectors. Exposure rules to large borrowers are often relaxed to allow specific industries or companies to survive.

12 Sometimes, independent central banks have been granted an exception from the constitutional ruling and are allowed to issue binding regulations over their specific sector. Austria is a case in point (see Grünbichler, 2005).
} 
Moreover, if the power of license revocation is in the hands of another government agency or the minister himself, the threat by the supervisor could be empty and his other powers undermined.

To strengthen supervisory independence, one of the most important requirements is that supervisors enjoy legal protection in the performance of their duties. The absence of proper legal protection in many instances has a paralyzing effect on supervision. Other tools to strengthen supervisory independence include appropriate salary levels for supervisors - as a way of attracting better-qualified individuals who have more confidence in their own judgment and who may be less prone to bribery - and the use of a rules-based system of sanctions and interventions that removes the scope for discretion in individual cases. ${ }^{13}$ Providing for appeals against supervisory actions to be heard only in specialist tribunals may also help to guard against excessive appeals by supervised entities or the bringing in of deliberately vexatious cases.

\section{Budgetary independence}

Budgetary independence refers to the ability of the supervisory agency to determine the size of its own budget and the specific allocations of resources and priorities that are set within the budget. Supervisory agencies that enjoy a high degree of budgetary independence are better equipped to withstand political interference (which might be exerted through budgetary pressures), to respond more quickly to newly emerging needs in the area of supervision, and to ensure that salaries are sufficiently attractive to hire competent staff.

A supervisory agency that is funded through a ministry that exercises oversight of its operations, or by appropriations from the general government budget, is open to various forms of political interference. For instance, the government could threaten to withhold funding (or to reduce it) if the supervisors are deemed to be too strict on politically linked financial institutions. Moreover, its budget might be cut at times of fiscal austerity-and those times often coincide with mounting problems in the banking system-needing greater supervisory attention. If, for whatever reason, there is a consensus that funding needs to come from the government budget, the supervisory budget should be proposed and justified by the agency, based on objective criteria related to developments in the markets.

Funding via a levy on the regulated entities reduces these risks. However, unless the levy is properly structured, it may produce a sense of budgetary dependence on the industry. To avoid industry capture and ensure that the fees are reasonable, in some countries, their level is determined jointly by the supervisory agency and the government. Fee-based funding is also vulnerable to the risk that the supervisor's resources will be most limited when the industry is under strain. Allowing the agency to build up reserve funds for such periods seems the best solution.

\footnotetext{
${ }^{13}$ An example would be prompt corrective action. However, there is a trade-off between the gains in terms of protection and independence and the very real drawbacks of taking away the supervisors' discretion in individual cases.
} 


\section{B. The Dimensions of Accountability}

The premise offered in Hüpkes, Quintyn, and Taylor (2005b) is that well-designed accountability mechanisms can help to strengthen agency independence; in other words, independence and accountability are complementary. Thus, the concept of a "trade-off" between independence and accountability is flawed to the extent that it assumes that stronger accountability mechanisms must necessarily mean a less-independent regulatory agency. However, where the notion of the trade-off does identify a genuine issue, is that poorly designed accountability mechanisms or "control" mechanisms masquerading as accountability arrangements - for example, those that give the minister of finance the authority to intervene in agency decisions - are corrosive of agency independence and, in the long run, are likely to be incompatible with it.

The essence of designing accountability arrangements that will be supportive of agency independence is to create a network of complementary and overlapping checking mechanisms. The goal of using such a combination of arrangements is to arrive at a situation where no one controls the agency, but the agency is nonetheless "under control."14 The possibility of creating such a network of complementary checking mechanisms is assisted by the fact that regulatory agencies operate in a multiple-principals environment, and, therefore, for each dimension of independence, accountability to more than one principal will be involved. The main principals are the executive, legislative, and judicial branches of government plus the regulated industry itself and the public at large (customers of financial services).

The best way to ensure that mechanisms of accountability do not undermine independence is to observe the principle of transparency. It encourages open administration and serves the function of enhancing public confidence in the financial supervisor. Transparency is implemented by way of publications, typically on the agency's website, of all regulations, supervisory practices and important decisions (within the confines allowed by confidentiality and market-sensitivity requirements), annual reports, as well as regular press conferences and information events. For each of the four dimensions of independence, corresponding dimensions of accountability can be identified. ${ }^{15}$

\section{Institutional accountability}

\section{Legislative branch}

In most systems of government, the legislative branch plays a vital role in overseeing the activities of the executive branch by virtue of its representative character. The objective of its oversight is to ensure that public policy is administered in accordance with legislative intent.

\footnotetext{
${ }^{14}$ Majone (1994) and Moe (1987).

${ }^{15}$ For a more elaborate presentation and justification of the accountability arrangements, see Hüpkes, Quintyn, and Taylor (2005b).
} 
Since the principles of regulatory regimes are normally promulgated by parliament, the latter should be a primary actor charged with holding the financial supervisor accountable for meeting the stated objectives in its mandate. To ensure that these objectives are met, there should be regular institutionalized contacts between the RSA and parliament. ${ }^{16}$ Nonetheless, the latter should not exercise immediate powers over the agency or interfere directly in its supervisory activities by issuing concrete guidance. Instead, parliament's influence on the supervisory activities ought to be exerted primarily through its law-making powers, i.e., by making changes to the legal framework when needed.

In most jurisdictions that have established a mechanism of accountability to the legislative branch, the regulatory agency is answerable to a parliamentary committee. This permits individual members of parliament to develop expertise on the complex financial and technical issues dealt with by the regulatory agency. Committees can also ensure a greater degree of continuity of the monitoring function. These committees generally have the power to summon the agency's chief executive to appear before them or to report to them.

\section{Executive branch}

An independent RSA needs to have a direct line of accountability — or communication - to the executive branch because the latter bears the ultimate responsibility for the general direction and development of financial policies, and the minister of finance needs to be aware of developments in the financial system. In most jurisdictions, the government will also play an active role in financial crisis management. Formal channels of communication should include the annual report, as well as regular reporting (monthly, quarterly). Such formal reporting should be complemented with a regular dialogue between the agency and the minister of finance. Information about the supervised sector, however, should only be disclosed in aggregate format. No individual or confidential bank data should be shared under normal circumstances, and protection of the confidentiality of supervisory information is usually enshrined in law.

In some countries, the ministry of finance is the formal oversight authority of the financial supervisor, but such an accountability relationship may raise concerns regarding the financial supervisor's independence. There is a fine line between reporting and consultations, on the one hand, and the exertion of political influence on the other. The ministry's role should exclude any direct involvement in operational and policy decisions. Oversight can easily become a control function whereby political influence is exerted on the agency. The type of accountability arrangements that would be most consistent with agency independence include reporting by the supervisory agency on a regular basis, as well as the possibility of the executive requesting information or conducting consultations with the regulatory agency.

\footnotetext{
${ }^{16}$ In jurisdictions where the minister is directly answerable to parliament, the agency generally submits its annual report to parliament via the finance minister, and parliament holds the agency accountable through the minister (indirect accountability).
} 
Some countries have tried to establish accountability to the executive branch by appointing government representatives on internal oversight bodies. However, representation of government or ministries should be limited to nonexecutive members in an oversight board without operational or policy functions. Once they are involved in policy matters, compliance with "operational independence," as defined in Basel Core Principle 1, is debatable.

The executive branch also has an important role to play in the appointment of the senior officials of the regulatory agency. In many countries, they are appointed by the government or by the head of state upon recommendation by the government or finance minister. Ideally, the legislative branch should appoint senior officials, upon recommendation of the government. While the right to appoint the chief executive and/or members of the agency's board for a fixed term enhances independence, the right for removal on clearly specified grounds is an indispensable accountability mechanism. ${ }^{17}$ Some governments have the right to arrange independent inquiries into regulatory matters of concern. However, this power should belong to parliament, not to the government.

\section{Regulatory accountability}

A regulatory agency that has rule-making authority needs to be held accountable for the way in which it exercises its authority. Given that the rule-making powers of the supervisory agency will usually be made under a delegation from the legislature, the exercise of this authority will need to be one of the main topics of the reporting to the legislative branch discussed above. Since parliament also possesses the ultimate mechanism for changing the legal basis on which the agency acts, accountability to parliament also provides an opportunity for a dialogue on the quality of the legal framework, during which the agency should have an opportunity to voice any concerns in its supervisory practices that could be corrected in the form of legislative amendments.

Supervised institutions also form a significant group in the exercise of accountability with respect to regulatory rule making. Their participation in policy making through consultation procedures serves to achieve greater acceptability and effectiveness of the regulatory process and also increases the agency's legitimacy. The agency should have in place arrangements for involving representatives of affected interests on the appropriateness and practicality of proposed rules. The RSA should undertake, to the extent possible, an assessment of the regulatory effectiveness and the costs to the industry. Accountability to the industry (and, in some cases, to users of financial services) can also be achieved through appropriate representation on an oversight board.

\footnotetext{
${ }^{17}$ Dismissal procedures are of relative value, if dismissal is limited to cases of malfeasance. In no instance is serious misconduct interpreted as including the failure to discharge functions properly in accordance with the statutory objectives of the financial supervisor and, thus, in terms of bad performance (Amtenbrink, 1999).
} 


\section{Supervisory accountability}

Given the extensive legal powers typically conferred on regulatory agencies, judicial review is a cornerstone of their accountability relations in respect of supervisory measures. ${ }^{18}$ Any independent agency must be accountable to those who are affected by its decisions. The latter should have some right of legal redress in court. Judicial review provides a procedure whereby the courts oversee the exercise of public power. Traditionally, the purpose of judicial review of administrative action is to ensure that the decision maker acts within its powers. It applies to the process (procedural accountability), and, in some cases, albeit to a lesser extent, to the outcome (substantive accountability).

It is generally accepted that individuals or institutions subject to the agency's decisions have the right to apply to a judicial authority for review of those decisions. Natural justice requires that the agency must observe a number of due-process requirements when it takes decisions, such as issuing or withdrawing licenses and imposing sanctions. Once a formal decision has been taken, the party to whom the decision is addressed must be informed of his or her legal remedies. The purpose of these requirements is to ensure that the procedure is as transparent as possible and that it results in a fair and just decision.

Judicial review also serves to review the merits and facts of the case and to verify the legality of its conclusions. The difficulty here is that the discretion conferred on a supervisor is typically broad, and courts in practice exercise restraint and defer to the expert knowledge of the supervisor, given that they do not normally possess the expertise in financial matters and are therefore reluctant to substitute their judgment on supervisors. Substantive accountability is therefore of less significance and judicial review is generally limited to the review of legality with a view to ensuring that discretion is not exercised in bad faith or for improper purposes. ${ }^{19}$ Judicial review needs to be limited and time-bound in order to avoid that the process will stand in the way of regulatory and supervisory efficiency and effectiveness and, ultimately, undermine agency independence.

In the event that a regulatory agency is found to have breached its legal duties, the plaintiff must have some remedy available. However, the need to ensure agency independence means that there should be a variety of limitations on liability for supervisory mistakes. Any official of an agency who takes action in good faith should not be held personally liable for damages caused in the exercise of his functions. Because rules on immunity and limited liability of the supervisor are correlates of independence, their existence needs to be compensated by appropriate accountability arrangements, including judicial review and a procedure that offers administrative compensation in cases where loss was suffered due to unlawful action by the agency.

\footnotetext{
${ }^{18}$ The term "judicial review" is generally limited to the review of the lawfulness of a decision or action taken by a public body and, as such, distinguishable from the term "appeal," which involves a reexamination of all facts and the merits of the case. Here, the term "review" is, however, used in a broader sense encompassing all legal remedies that can be taken to amend or invalidate a decision or action taken by an RSA.

${ }^{19}$ Hüpkes (2000).
} 


\section{Budgetary accountability}

An important instrument of agency accountability is the presentation of financial accounts, demonstrating the regularity of expenditures. At the same time, however, this aspect of accountability should not become a way of undermining agency independence by the back door. The autonomy of the agency in the determination of its budgetary needs and the allocation of priorities is the cornerstone of independence.

To maintain agency independence, financial accountability should generally be limited to ex post budgetary accountability, which focuses on a review of the annual accounts and balance sheets by independent auditors to determine whether there has been proper financial management, whether the authority is managing its resources in an efficient way, and whether financial reports represent a true and fair view.

The various dimensions of accountability are summarized in Table 1.

\section{What Are the EMerging Trends?}

\section{A. Methodology}

To find out to what extent the need for regulatory independence and accountability has been embraced by governments, and which of the operational arrangements described in the previous section have found their way into new legislation, and which ones are not liked by the governments, this section analyzes the results of a survey of the legal framework of a sample of 32 countries that went through reforms (institutional or purely legislative) of their supervisory frameworks in, roughly, the past decade-and-a-half. The focus is on bank supervisory agencies because of their importance to financial stability. ${ }^{20}$ The paper tries to answer questions such as (i) Have countries taken the opportunity of legislative and/or organizational reforms to enhance the independence of their RSA? (ii) What is happening to accountability arrangements? Are these also being strengthened to support independence? (iii) Does one type of reform yield different results in terms of independence and accountability than another? and (iv) Which dimensions of independence and accountability are more easily implemented, and which ones prove to be hurdles for the governments?

\footnotetext{
${ }^{20}$ Thus, the paper analyzes independence and accountability arrangements of the agency in charge of bank supervision before and after the reforms. This can be the central bank, a separate agency, or a unified supervisor (partly or fully unified). This choice implies that for the two countries in the sample that adopted the "twin peaks" model (Taylor (1995) and (1996)) - Australia and the Netherlands-we analyze the agency that is in charge of prudential bank supervision, respectively, APRA and the Netherlands Bank, and not the agency in charge of the supervision of market conduct. In Germany and Japan, the central banks continue to be intensely involved in the actual supervision of banks (off-site monitoring and on-site inspections). For the purposes of this paper, the ratings are based on the enabling legal framework for the unified supervisors (Bafin and JFSA, respectively), because those are after all the institutions that set and enforce the regulatory framework.
} 
Table 1. Mapping Accountability Arrangements

\begin{tabular}{|c|c|c|}
\hline Accountability to Whom & Content and Form & Type of Arrangements \\
\hline \multirow[t]{5}{*}{ Legislative branch } & $\begin{array}{l}\text { Regular report (annual) to assembly or } \\
\text { committee; }\end{array}$ & Ex post-explanatory \\
\hline & $\begin{array}{l}\text { - Ad hoc questioning and oral } \\
\text { presentations; }\end{array}$ & Ex post-explanatory \\
\hline & $\begin{array}{l}\text { - Ad hoc presentations of proposals for } \\
\text { new laws; }\end{array}$ & $\begin{array}{l}\text { Ex ante-explanatory or } \\
\text { amendatory }\end{array}$ \\
\hline & - $\quad$ Presentation of budgetary outcome; and & Ex post-financial accountability \\
\hline & - $\quad$ Audit report. & $\begin{array}{l}\text { Ex post-financial accountability, } \\
\text { explanatory or amendatory }\end{array}$ \\
\hline \multirow[t]{2}{*}{ Executive branch } & $\begin{array}{l}\text { - Regular report to minister of finance or } \\
\text { government; }\end{array}$ & Ex post-explanatory \\
\hline & $\begin{array}{l}\text { Ad hoc formal presentations, } \\
\text { information on sectoral developments; } \\
\text { and } \\
\text { Proposals for new government } \\
\text { regulations /decrees. }\end{array}$ & $\begin{array}{l}\text { Ex post-explanatory, often pure } \\
\text { informational } \\
\text { Ex ante-explanatory or } \\
\text { amendatory }\end{array}$ \\
\hline \multirow[t]{2}{*}{ Judicial branch } & - Judicial review; and & Ex post—amendatory, procedural \\
\hline & $\begin{array}{l}\text { - Supervisory liability for supervisory } \\
\text { mistakes. }\end{array}$ & $\begin{array}{l}\text { Ex post_-amendatory and } \\
\text { substantive accountability }\end{array}$ \\
\hline \multirow[t]{3}{*}{ Supervised industry } & - Consultation on new regulations; & $\begin{array}{l}\text { Ex ante and ex post-explanatory, } \\
\text { amendatory }\end{array}$ \\
\hline & $\begin{array}{l}\text { - Regulatory impact analysis and cost- } \\
\text { benefit assessments; and }\end{array}$ & Ex ante and ex post-explanatory \\
\hline & $\begin{array}{l}\text { - Information on regulatory and } \\
\text { supervisory practices on the website, } \\
\text { annual reports, press conferences and } \\
\text { public statements of representatives of } \\
\text { the RSA. }\end{array}$ & $\begin{array}{l}\text { Ex ante or ex post depending on } \\
\text { issue-explanatory }\end{array}$ \\
\hline \multirow{4}{*}{$\begin{array}{l}\text { Customers and public at } \\
\text { large }\end{array}$} & - Mission statement; & Ex ante and ex post-explanatory \\
\hline & $\begin{array}{l}\text { Information on regulatory and } \\
\text { supervisory practices on the website, } \\
\text { annual reports, press conferences and } \\
\text { public statements of representatives of } \\
\text { the RSA; }\end{array}$ & Ex ante and ex post-explanatory \\
\hline & - Consumer education; and & Ex post-explanatory, amendatory \\
\hline & $\begin{array}{l}\text { Ombudsman schemes and consumer } \\
\text { grievance board (United Kingdom). }\end{array}$ & Ex post-explanatory, amendatory \\
\hline
\end{tabular}


Notes:

- Ex ante accountability refers to reporting before action is taken, for instance, consultations with the stakeholders on supervisory and regulatory policies. Ex post accountability refers to the reporting after action has been taken, for instance, the submission of annual reports to parliament.

- The duty to answer or explain is captured in the notion of explanatory accountability, which requires the giving of reasons and the explanation of action taken. Amendatory accountability refers to the obligation to redress grievances by taking steps to remedy defects in policy or regulatory rule making.

- Procedural accountability refers to requirements imposed on the process to be followed by the accountee when taking action, for instance, due-process rules. Substantive (or functional) accountability seeks to make sure that regulatory and supervisory actions are justifiable in terms of the objectives to be pursued.

- Personal accountability refers to the discharge of responsibilities delegated to individuals (e.g., the president of the agency).

- Financial accountability refers to the presentation of proper financial statements.

- Performance accountability refers to the extent to which (measurable) objectives and criteria are met.

\section{Sample}

The paper selected a sample of countries where the bank supervision agency underwent changes in recent years. While this sample does not represent the entire universe of reformed agencies, the aim has been to construct a representative group of countries with a variety of reasons for change, as well as a variety of types of changes. ${ }^{21}$ Among the 32 countries, the bank supervisory agencies in 13 of them underwent changes only in the enabling legislation, while in the other 19 countries institutional changes (with concomitant legislative changes) were introduced.

All these reforms were responses to a variety of external factors. In some of the 13 countries that underwent purely legislative changes, these were introduced at a time when other institutional changes in the supervisory landscape were undertaken. The Bahamas, Mauritius, South Africa, and Uganda integrated their nonbank supervisors and took the opportunity to modify the legal framework for bank supervision, but without changing its institutional location. In the Netherlands, the central bank - already the bank supervisor-took on additional prudential supervisory functions, and, at the same time, a second "peak" was established outside the central bank, the Authority for Financial Markets, in charge of the conduct-of-business supervision. ${ }^{22}$ In some other countries, the response to a crisis was in the form of legislative changes (e.g., Ecuador). Finally, several countries simply aimed at

\footnotetext{
${ }^{21}$ Appendix I provides key data on the supervisory structures of the countries in this sample.

${ }^{22}$ See Kremers, Schoenmaker, and Wierts (2003).
} 
"modernizing" the legislative framework to bring it closer to international standards, as promoted in the BCPs (Canada, Chile, and Poland, for instance). ${ }^{23}$

The countries that went through some form of organizational change (partial or total integration of supervisory functions) did so in response to either trends in the financial system (for instance, Australia, the Baltics, Colombia, Germany, Hungary, the Scandinavian countries, Turkey, Trinidad and Tobago, and the U.K.), a financial crisis (e.g., Indonesia, Korea, and Mexico), or long periods of financial distress (China and Japan). Within the Euro-zone, the transfer of monetary policy responsibilities to the European Central Bank prompted a reshuffling of financial sector responsibilities inside some countries (e.g., Ireland). In other countries, a combination of the above factors was at work (e.g., Austria and Belgium).

Moreover, with respect to the prior institutional arrangements for banking supervision, the sample includes countries where bank supervision was previously under the ministry of finance (Austria and Turkey); where it was moved out of the central bank to a new, unified supervisor (e.g., the U.K.); where some (e.g., the Netherlands) or all (e.g., Ireland) types of supervision were brought together within the central bank, or where a reorganization took place of agencies that were outside the central bank (e.g., Belgium).

\section{Criteria}

The approach in this paper is in many ways similar to the one adopted to measure central bank independence. ${ }^{24}$ The paper limits itself to a de iure approach, i.e., independence and accountability arrangements are rated on the basis of what the enabling legislation stipulates. It is acknowledged that this approach has its limitations - as is also emphasized in the central bank independence literature, which has moved on, over the years to the combination of a de iure and de facto approach — because independence and accountability arrangements may actually operate differently in day-to-day practice. The paper differs from most central bank independence literature in that accountability arrangements are also measured and analyzed in conjunction with independence. ${ }^{25}$

\footnotetext{
${ }^{23}$ At the time of the finalization of this paper, the Polish authorities were in the process of establishing a unified regulator outside the central bank. This reform has not been taken into account in this paper.

${ }^{24}$ Measurement of central bank autonomy was pioneered by Bade and Parkin (1977), Cukierman (1992), and Grilli, Masciandaro, and Tabellini (1991). For a recent overview and update of this literature, see Arnone, Laurens, and Segalotto (2006a and 2006b).

${ }^{25}$ Measurement of central bank accountability is of a more recent date, and, certainly, is not as explored as the independence aspect. For empirical contributions, see de Haan, Amtenbrink and Eijffinger (1999) (central bank independence and accountability); Eijffinger and Geraarts (2003) (central bank transparency); and Oosterloo and de Haan (2003) and (2004) (central bank accountability with respect to its financial stability objective).
} 
Based on the operational aspects of independence and accountability, discussed in the previous section, we identified 19 criteria to measure independence and 21 for accountability. These criteria are presented in Appendix II. They cover the four dimensions of independence and the various accountability arrangements that go with them. The number of criteria is longer than in the typical central bank independence literature. This reflects to a great extent the higher degree of complexity of banking regulation and, in particular, supervision, compared to the conduct of monetary policy.

The rating of each individual question is typically 0 (criteria not met) or 2 (fully met). Sometimes a ' 1 ' is given as a "partly met" (for instance, if the RSA cannot issue binding regulations for constitutional reasons, but, instead, issues additional guidelines with a formal character). In a few cases, a -1 rating is given for "bad" practices (as opposed to 0 for absence of any arrangement in that field). This is, for instance, when parliamentarians or a minister sit on the RSA policy board, or the law gives the minister of finance the opportunity to intervene in the workings of the RSA. As discussed in Hüpkes, Quintyn, and Taylor (2005a and 2005b), such practices are considered direct control mechanisms, which go against the true spirit of accountability and undermine independence.

In a number of cases, a specific practice can be classified as a criterion for either independence or accountability. The presence or absence in the law of clear dismissal criteria for the head of the RSA is one example. The law giving the minister the right to intervene is another one. (The latter is a "control" mechanism rather than an accountability arrangement and undermines independence.) In those cases, inevitably, there is an element of judgment involved in deciding whether to allocate such a criterion to independence or accountability. However, ultimately the decision has no great impact on the results, because we view independence and accountability as complementary and are most interested in the general outcome in terms of improvements in the quality of governance.

For each country, we applied the independence and accountability criteria to the legal framework preceding and following the changes. The results are presented as a percentage of the benchmark, i.e., the value obtained when each criterion had a 2 rating. At this stage, no weighing has been applied to the individual criteria. Even though this could be a useful exercise, it would bring additional elements of subjectivity into the analysis. ${ }^{26}$

\section{Sources}

A combination of sources has been consulted: the starting point for each country is the national legislation before and after the reforms (typically, a combination of the legislation on the supervisory agency and the banking law). Where laws were not clear or did not provide the answers, other sources were consulted, such as information from published Basel Core Principle assessments, undertaken individually or as part of Financial Sector Assessment Programs (FSAP), the database compiled by Barth, Caprio, and Levine (2001), publications by the Institute of International Bankers, and articles and papers written on

\footnotetext{
${ }^{26}$ It can be argued that giving a "-1" rating, as is done in some cases, is tantamount to applying some weighing.
} 
specific country cases. Local agencies were consulted in a few cases to resolve ultimate uncertainties.

\section{B. General Overview}

The general results are presented in Table 2 and in Appendices III-VI. Table 3 provides a summary overview of the trends. ${ }^{27}$ The first observation that catches the eye is the upward trend almost across the board in the independence and accountability ratings. The average of the total ratings (independence and accountability together) (first two columns) has gone up from 46 to 64 . The average for independence went up from 52 percent to 68 percent, and for accountability from 40 percent to 61 percent (last four columns of Table 2). Despite these positive trends, it is also fair to say that independence ratings, on average still below 70 percent, remain modest. Only two countries reach a rating higher than 90 percent. So, it seems that politicians still do not fully embrace the independence idea.

A second observation is that accountability, starting from a low level, is receiving more attention than before. This upward trend - stronger than in the independence ratingsreflects a fairly general concern that supervisors need to be more accountable than in the past. As will be discussed and documented in the section on individual country experiences, the trend also reflects uneasiness (or frustration) of the political class in a number of countries with the lack of accountability of their central banks. ${ }^{28}$

Thus, despite the upward trends, the results are not unambiguously positive. The commitment to independence is not wholehearted, and the confidence in accountability arrangements, and, hence, in the interaction between accountability and independence, is not full. Two factors seem to be underlying the trends that we observe. First, that deciding about independence and accountability for RSAs is a new and largely unfamiliar area for policymakers. Second, and to some extent related to the first one, that politicians have a (residual) fear of granting independence to RSAs and compensate for this by imposing more accountability arrangements, or under the name of accountability, control arrangements. The presence of both factors is substantiated in what follows.

\footnotetext{
27 The individual country ratings can be obtained from the authors upon request.

${ }^{28}$ In this respect, see for instance Amtenbrink (1999) and Oosterloo and de Haan (2003) and (2004). In the analysis of their survey on central bank accountability with respect to the financial stability function, Oosterloo and de Haan (2003) and (2004) report that five central banks argue that they are not accountable because of their independence (italics are ours).
} 
Table 2. Independence and Accountability: Overview of Ratings Before and After Reforms

(In percent of benchmark)

\begin{tabular}{|c|c|c|c|c|c|c|}
\hline \multirow[b]{2}{*}{ Country } & \multicolumn{2}{|c|}{ Total } & \multicolumn{2}{|c|}{ Independence } & \multicolumn{2}{|c|}{ Accountability } \\
\hline & Before After & & Before After & & Before After & \\
\hline Australia & 4871 & & 5376 & & 4367 & \\
\hline Austria & 3564 & & 3779 & & 3350 & \\
\hline Bahamas & 4970 & & 6684 & & 3357 & \\
\hline Belgium & 5076 & & 6392 & & 3862 & \\
\hline Canada & 5963 & & 5555 & & 6269 & \\
\hline Chile & 5666 & & 6666 & & 4867 & \\
\hline China & 1636 & & 1334 & & 1938 & \\
\hline Colombia & 4570 & & 4768 & & 4371 & \\
\hline Denmark & 4563 & & 5363 & & 3862 & \\
\hline Ecuador & 5566 & & 7987 & & 3348 & \\
\hline Estonia & 6166 & & 8279 & & 4355 & \\
\hline Finland & 3469 & & 2471 & & 4367 & \\
\hline Germany & 5563 & & 4747 & & 6276 & \\
\hline Guatemala & 3035 & & 1621 & & 4348 & \\
\hline Hungary & 3463 & & 3463 & & 3362 & \\
\hline Indonesia & 4178 & & 5095 & & 3362 & \\
\hline Ireland & 6184 & & 7687 & & 4881 & \\
\hline Japan & 5155 & & 6147 & & 4362 & \\
\hline Korea & 4053 & & 4247 & & 3857 & \\
\hline Latvia & 6176 & & 8287 & & 4367 & \\
\hline Mauritius & 515 & 6 & 717 & 1 & 334 & 3 \\
\hline Mexico & 3171 & & 1882 & & 4362 & \\
\hline Netherlands & 6875 & & 7984 & & 5767 & \\
\hline Nicaragua & 5865 & & 7979 & & 3852 & \\
\hline Norway & 3958 & & 3953 & & 3862 & \\
\hline Poland & 4859 & & 4255 & & 5262 & \\
\hline South Africa & 3354 & & 3755 & & 2952 & \\
\hline Sweden & 5863 & & 4747 & & 6776 & \\
\hline Trinidad and Tobago & 4363 & & 5874 & & 2952 & \\
\hline Turkey & 1971 & & 2982 & & 1062 & \\
\hline Uganda & 4059 & & 5866 & & 2452 & \\
\hline United Kingdom & 617 & 6 & 768 & 2 & 487 & 1 \\
\hline Mean & 4664 & & 5268 & & 4061 & \\
\hline Standard Deviation & 12.710 & .6 & 20.217 & .7 & 12.1 & 9.8 \\
\hline
\end{tabular}


Table 3. Overview of Changes in the Ratings

(Number of countries)

\begin{tabular}{lrc}
\hline & + & - \\
\hline Total 32 & 0 & 0 \\
Independence 24 & 6 & 2 \\
Accountability 32 & 0 & 0 \\
\hline
\end{tabular}

\section{Unfamiliarity}

Unfamiliarity with these new issues of RSA independence and accountability can be observed in a number of findings. The bottom of Table 2 illustrates that the standard deviations are relatively high in all cases and narrowed only slightly after reforms. This is a strong indication that countries still have very divergent views on the independence and accountability of RSA. In general, not all countries seem convinced of the benefits of RSA independence and of the role that accountability and political control should play. This point is further illustrated by Figure 1 and Appendix III.

On the one hand, the scatter-plot shows that the observations have moved to the upper right part of the graph. It also confirms the upward movement of accountability arrangements. However, on the other hand, and, more importantly, the graph also shows the wide dispersion of the observations, both before and after reforms. The correlation coefficients, before and after reforms, are 0.273 and 0.262 respectively. Both are insignificant at the 10 percent level. If the mutually supportive connection between independence and accountability had been genuinely recognized, one would expect observations close to the 45-degree line, and, ideally, in the top right quadrant of the chart. The fact that neither of these two conditions is really met, suggests, among others, that political leaders have sought to enhance the accountability of regulatory agencies without fully accepting the case for regulatory independence.

Looking at individual country ratings, the unfamiliarity thesis is further illustrated by the finding that in 12 countries the independence rating exceeds the accountability rating by 20 percentage points or more. This gap is significant and may be another indication of the fact that countries are not persuaded of the beneficial effects of the working of accountability. In the long run, such an imbalance could work against RSA independence. In the same vein, but in the opposite direction, we find also eight countries where the accountability rating is higher (sometimes significantly higher) after the reforms than the independence rating (compared to seven before, but not all the same). This shows that some governments are clearly still not persuaded by the case for independence and see accountability as a way to limit independence and not as a way to make independence effective. This leads us to the second factor, the fear of freedom. 


\section{Fear of Freedom: What Worries Governments the Most?}

A dissection of the trends underlying the independence and accountability ratings corroborates the presence of a lingering fear to grant independence. To make this point, Table 4 singled out 10 criteria on independence and 7 on accountability, which can be considered as more critical and, therefore, more controversial than some of the others in the survey. The results are expressed in the number of countries meeting the criteria (the total is 32 ). While we identify a number of indisputably good developments, other developments in critical areas confirm the fear thesis.

\section{Independence}

On independence, positive developments include (i) about 78 percent of the countries surveyed have put legal immunity for all supervisory staff in the law (up from less than 50 percent); (ii) in 16 countries, the RSA can now issue binding regulations, while in another 12 countries, they can issues guidelines with a more or less binding character; (iii) in 22 countries, the RSA is 100 percent funded outside the government budget (up from 10), while another 6 only partially rely on government resources; and finally (iv) defining dismissal criteria for the chair and board members is on the rise.

Other developments go in the right direction, but still hint at reluctance on the part of the governments to cede their influence. ${ }^{29}$ This is the case in particular for the licensing and delicensing process. After the reforms, in 21 countries (up from 17), or 68 percent of the sample, the RSA has the sole right to license new financial institutions. In six countries, another agency (typically, the ministry of finance) needs to give its final approval, while the number of countries where the supervisors have no licensing rights is still at five. When it comes to the right to withdraw licenses, the desire for the government to remain involved is even stronger. Following the reforms, 18 RSAs (less than 60 percent of the sample) have the sole power to withdraw licenses (up from 14), another 9 need the approval of the government, and 6 have no rights in this respect.

Finally, three other findings go to the heart of the fear-thesis. First, in only 47 percent of the cases, the law states that the supervisor is independent from the government. Although the number has doubled compared to the pre-reform period, this remains low. Secondly, in 12 countries ( 38 percent of the sample, an increase of one compared to pre-reform) the law gives the minister of finance the right to intervene in the working of the agency at his/her discretion. Thirdly, in 20 countries (one more than before the reforms), the minister or another government representative chairs or sits on the board of the agency. So, while several RSAs have received a large number of independence-attributes as defined in this paper, their governing laws include other provisions that are diametrically opposed to the spirit of agency

\footnotetext{
${ }^{29}$ For similar results, see de Luna Martinez and Rose (2003), who looked at changes in supervisory arrangements in a sample of countries that established a unified supervisor.
} 
independence, ${ }^{30}$ showing that several governments are not (yet) ready to grant full independence.

From the above findings, it can now be inferred that accountability ratings have increased faster than independence in a number of cases because measures that were introduced as accountability, but which are actually control measures (e.g., the minister as chairman of the board, parliamentarians as members of the board, or an explicit oversight role for the minister), suppress the independence ratings in our rating system. ${ }^{31}$ The presence of such arrangements and the confusion they create in the independence-accountability debate show that the thin line between accountability and control is not always well-understood, or, stronger, is proof of the politicians' distrust of independence rather than their confidence in accountability.

\section{Accountability}

On accountability, issues such as frequent reporting to, and consultations with, the government and the legislature are generally accepted practices. The survey indicates that newer aspects of accountability, such as ex ante consultations with the supervised industry, are increasingly accepted (22 countries, up from 6). Whereas the right to appeal by the supervised is now relatively present generally ( 28 countries), separate judicial processes and/or specialized judges are not yet common practice (not in the table).

The trend toward more accountability is, to some extent, also the outcome of external developments; in particular, the omnipresence of the internet, which facilitates transparency and, thus, has made accountability less costly. Annual reports, mission statements, and other information are now routinely found on websites and the internet has reduced the cost of communication with the public and has improved efficiency. An additional improvement is that most websites also present the most critical information in English.

On the other hand, more newly acquired ideas in the accountability area, such as having consumer boards and consultation fora with the public at large on new rules and regulations still need time to become more widely accepted. Nine countries made consultation with the public at large mandatory, while six have a consumer board (plus one in Canada, which is established as a separate independent agency, be it with a wider mandate).

\footnotetext{
${ }^{30}$ There are even a few countries where the law explicitly states the agency's independence and provides the minister with the possibility to intervene. The formulation of this right to intervene differs greatly from country to country (for instance, "has the right" versus "may"), and can go from very specific to very vague. We did not consider such a stipulation as a "negative" in our ratings when it explicitly stated that this right could be exercised in times of crisis, because it is generally accepted that, in those times, the minister should play a role in crisis management (Hoelscher and Quintyn (2003)).

${ }^{31}$ See also Hüpkes, Quintyn, and Taylor (2005a) about the "do's” and “do not's" with respect to accountability.
} 
Figure 1. Ratings Results for Selected Countries

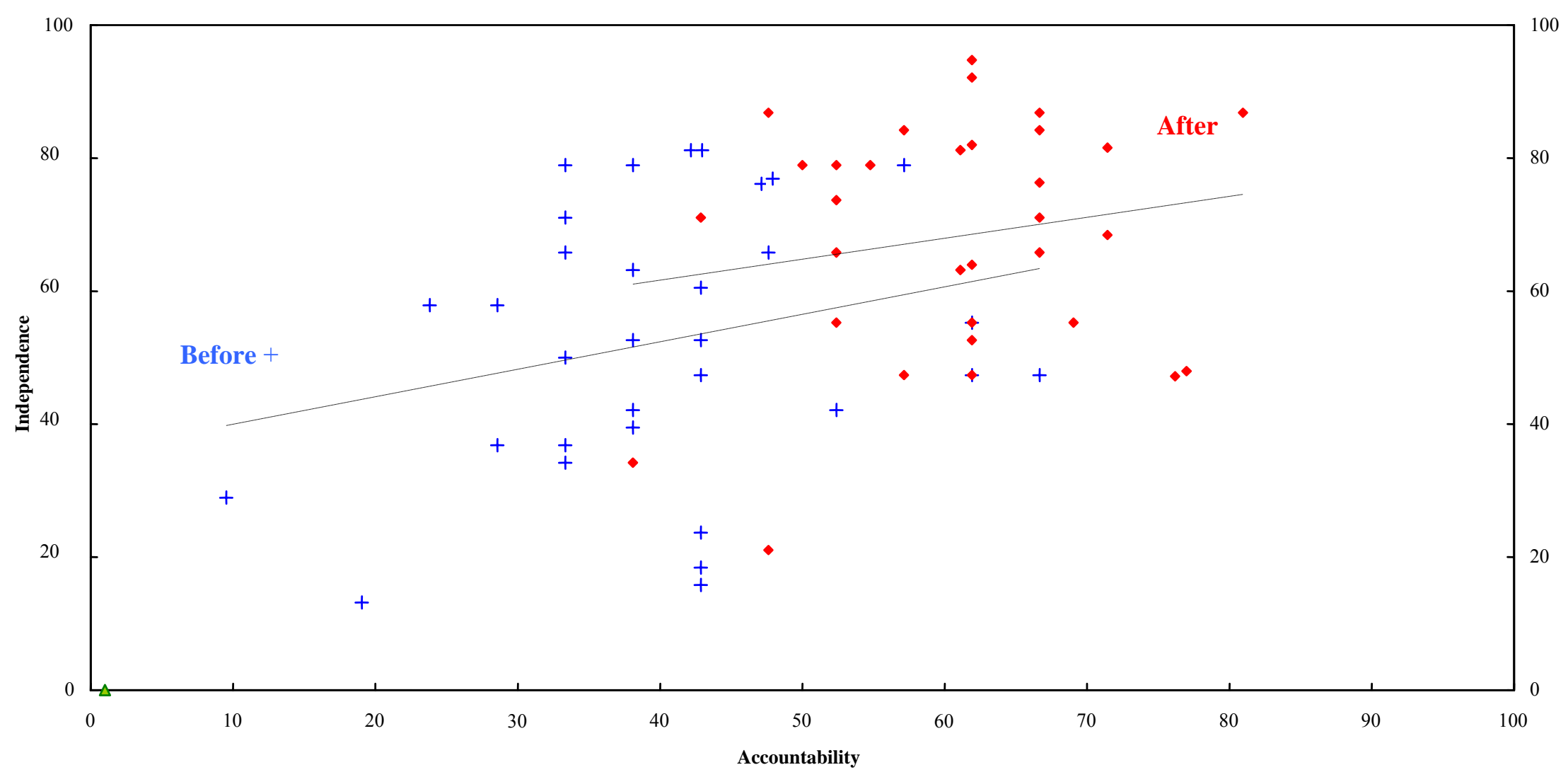


Table 4. Analysis of Changes in Meeting Specific Independence and Accountability Criteria (Number of countries fully or partially meeting the criteria)

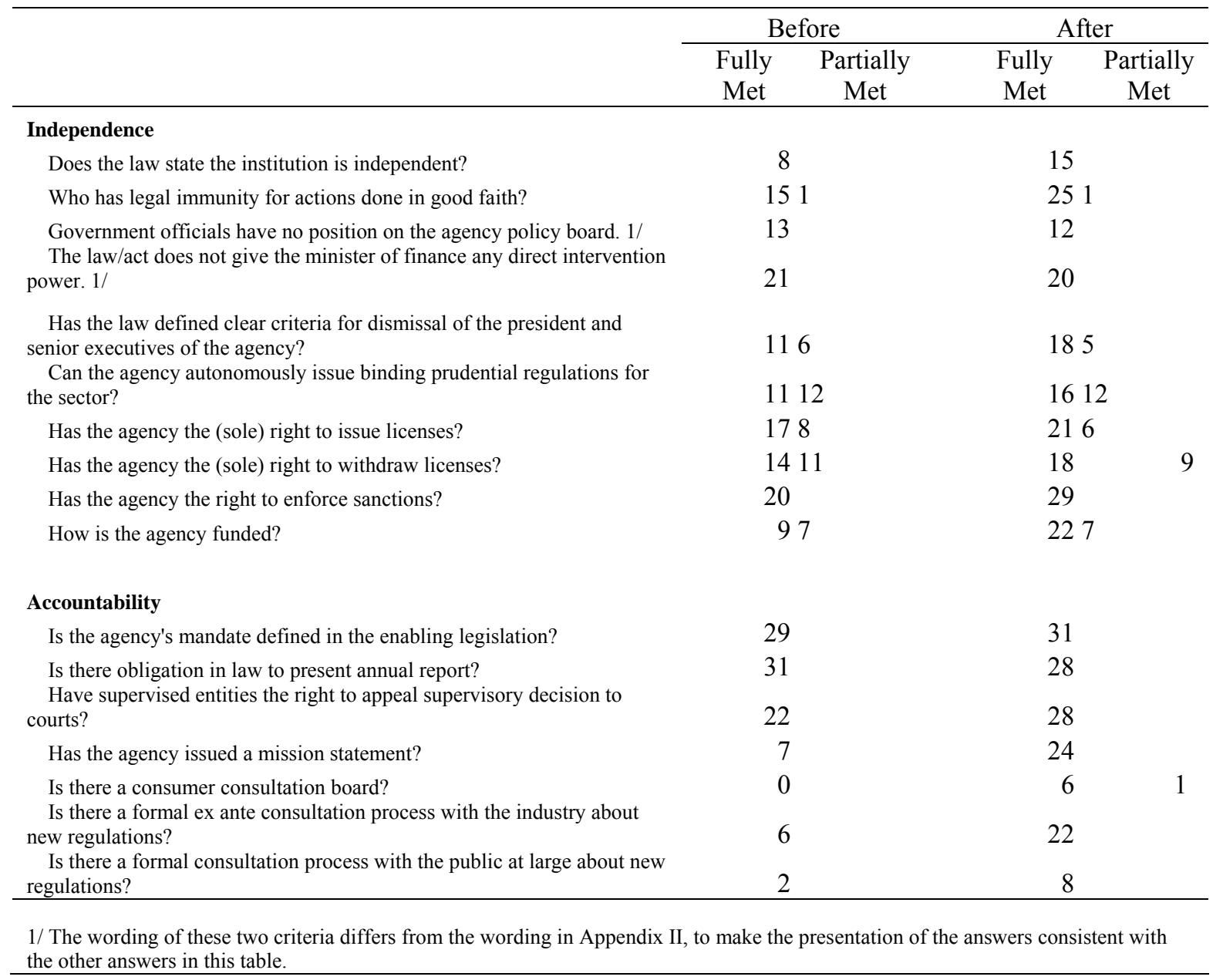

In sum, some of the more encouraging signs on individual independence and accountability arrangements tend to be overshadowed by the finding that in more than a third of the surveyed countries, governments are directly represented on the decision-making body and/or prefer to keep a door open for intervention in the activities of the RSA, when considered necessary. Such stipulations tend to undermine the credibility of the independence arrangements, as well as the accountability arrangements, as they open the door to more direct control.

This finding points to a fair degree of ambiguity in the minds of governments with respect to granting independence to RSAs. The theoretical case for regulatory independence may be more widely recognized than in the past, but, in practice, it is being adopted in a rather half-hearted way. Moreover, the distinction between accountability and control is still not well understood, with some governments expressing their apparent doubts about the effectiveness of accountability arrangements by retaining an intervention clause in the law. The idea that well-designed accountability arrangements might actually be used to support 
independent regulatory agencies is also not widely accepted as yet. Rather, governments seem to believe in a trade-off between independence and accountability, and their revealed preference is for more accountability, often under the form of control.

\section{E. A Closer Look at Individual Countries}

To illustrate the points made above, but without attempting to be exhaustive, this section will connect some of our findings with background information available on individual countries. Australia, Belgium, Indonesia, Ireland, Latvia, Mexico, the Netherlands, Turkey, and the U.K. are countries with the highest ratings (over 70 percent, see Table 2). In this group, four countries adopted a unified supervisory structure (Belgium, Ireland, Latvia, and the U.K.), while two others - Australia and the Netherlands - adopted a "twin peaks" structure. Several countries among this group - Australia, Belgium, Indonesia, and Turkey - also have the most significantly improved scores over the period of our survey.

Those countries displaying a relatively high score for independence include Belgium, Indonesia, the Netherlands, and Turkey.

- The Netherlands already scored well before the reforms. As part of the Netherlands Bank, banking supervision traditionally enjoyed a high degree of independence. The accountability rating is slightly lower, due to a general factor that central bank accountability is typically geared toward the monetary policy function and, therefore, not always well-fitted to the requirements of banking supervision.

- The Belgian Banking Commission has traditionally enjoyed a high degree of independence and the gradual integration of other parts of supervision has left this situation untouched. However, there is a considerable gap between independence and accountability ratings.

- The drastic increase in the ratings in Turkey stems from the fact that, until 2000, banking supervision was a department within the treasury. The new agency, the Banking Regulatory and Supervisory Agency (BRSA) now enjoys a great deal of independence.

- In response to the 1997 financial crisis, the law governing Bank Indonesia was revised to bolster central bank independence. The strengthening of Bank Indonesia's independence was followed some years later by revisions intended to improve its accountability. Bank Indonesia has now a regime whereby most of the accountability runs to and through parliament, with limited interaction with the government-a unique arrangement among the surveyed countries. Indonesia also planned to adopt a unified supervisory structure, but legislative and administrative hurdles have delayed the project. As a result, the transfer of bank supervision from Bank Indonesia to the new structure has been postponed until 2010.

The countries with the highest scores on accountability include Australia, Ireland, and the U.K. On the part of Australia and the U.K., this may reflect the Anglo-Saxon tradition, which has always put more emphasis on the accountability of office-holders than in many other 
parts of the world. In addition, Ireland and the U.K. both decided to establish a mega-regulator, which, as indicated in the introduction of this paper, often raises fears about creating an over-mighty agency. Hence, much attention was given to proper accountability arrangements in the run-up to the establishment of these institutions. ${ }^{32}$

The debate about the reforms in all three countries has been well documented.

- $\quad$ Reforms in Australia were preceded by a very transparent public debate (Carmichael, 2004). The country opted for the twin-peaks model, with the Australian Prudential Regulation Authority (APRA) responsible for regulation and supervision of all financial institutions with the exception of the securities sector. The final report of the Wallis Commission (Commonwealth of Australia, 1996) explicitly mentioned the need to increase the accountability of the new agencies. In the end, APRA's independence and accountability were strengthened considerably and in a balanced manner.

- $\quad$ In the U.K., the FSA was established against the background of a grant of greater monetary policy autonomy for the Bank of England, part of the price for which was the loss of its banking-supervisory function. In the wake of the BCCI and the Barings cases, the political class wanted a supervisory institution that was more accountable than the Bank of England had been (see Westrup, forthcoming, and other sources cited therein). The outcome of this political balance is clearly visible in the ratings, as independence has increased, but is certainly lower than what a corresponding rating for the Bank of England would be, following the reforms, while accountability has increased dramatically. Westrup (forthcoming) notes that the center-left government wanted clear accountability toward the customers of financial services, hence, the innovation of a consumer board. The upshot is an agency that has fairly balanced ratings, although some elements of control remain present.

- The Irish case is interesting in that the new structure is woven into the structure of the central bank, and yet it has also kept some distance from the bank. The Irish Financial Regulatory Authority largely benefits from the independence of the central bank, ${ }^{33}$ and has an accountability structure of its own. The accountability arrangements include, as it does for the FSA in the U.K., a formal relationship with users of financial services. The Irish case also reveals (Westrup (2002) and (2005)) some issues that further need to be explored in the ongoing reform wave: in some respects, the relationship between the central bank and the regulator is a parent/subsidiary relationship, as reflected in the fact that several of the regulator's accountability arrangements are geared toward the central bank. For example, the law stipulates that the governor of the bank should be involved in the selection process of the head of the IFSRA.

\footnotetext{
${ }^{32}$ See, for instance, for the U.K., Graham (1998), Goodhart (2001) and Page (2001).

${ }^{33}$ Although its independence is restricted in some ways. For instance, it cannot issue regulations.
} 
Countries that showed balanced improvements in both independence and accountability arrangements included Austria, the Bahamas, Finland, Hungary, and Trinidad and Tobago.

- $\quad$ Before the reforms, Austrian banking supervision was housed in the ministry of finance. The establishment of the unified supervisor, the Financial Market Authority (FMA) improved independence and accountability arrangements significantly. Grünbichler (2005) explains how theses arrangements needed to be carefully tailored to stay within the confines of Austrian constitutional law. In his view, the agency received as much independence as feasible under the constitution.

- Hungary's reforms (2000) also went as far as possible, given the country's constitution (the agency cannot issue binding regulations), but, subsequently in 2004, the government reversed course and introduced a number of control elements (on the appointment of the chair and the lines of accountability of the chair) in the operation of the Hungarian Financial Supervisory Authority (HFSA) (Balogh, 2005). These modifications are reflected in the ratings in this paper.

- $\quad$ Finland's improved scores reflect revisions to the legislation made in 2003, in the wake of the country's FSAP, which recommended strengthened independence and accountability arrangements.

A final group of countries have seen little or no improvement in the score for independence, mainly as the result of greater "control" mechanisms, but several of them also show improvements in the score for accountability. This group contains a number of countries that reformed in the wake of a financial crisis (Ecuador, Guatemala, and Republic of Korea) or extended periods of financial sector distress (China and Japan). Japan and Korea adopted a unified structure, China moved supervision out of the central bank, and the others only implemented legislative reforms. The common thread in all of these countries-with the exception of China - is that more control and accountability arrangements were introduced.

- $\quad$ Germany provides an example of reforms leading to greater accountability without any corresponding increase in independence. The supervisory restructuring debate in Germany was colored by the fact that both the political class and the banking industry wanted bank supervision to be in the hands of an agency that was less independent and more accountable than the Bundesbank, and which had a strong consumer orientation (Westrup, forthcoming). ${ }^{34}$ The end-result is reflected in the ratings: the new agency, Bafin, is no more independent than its predecessor (Bundesaufsichtsamt fur das Kreditwesen), but — even though this paper has no material to compare strictly - it is far less independent than the Bundesbank, generally considered the most independent central bank worldwide. Its accountability rating is the highest in the sample (and much higher than that of its predecessor). As Schüler (2005) notes, the

\footnotetext{
${ }^{34}$ Accountability of the Bundesbank has come up as a sensitive issue on several occasions. Oosterloo and de Haan (2003) and (2004) refer to section 12 of the Bundesbank Act (regarding its independence) which, according to their survey, implies that the Bundesbank has no accountability obligations. See also Amtenbrink (1999) and Lybek (1998).
} 
law gives the minister of finance the right to intervene, an element that reduces the agency's independence in our ratings.

- In Japan, following a decline in the ministry of finance's reputation as a supervisor in the 1990s, the government decided to create a new agency, the Financial Supervisory Agency, in charge of banking supervision, which would be more transparent than the ministry of finance had been (Hartcher, 1998). The agency is accountable to the prime minister's office, an arrangement that was the result of the authorities' desire to remove the potential conflicts of interest inherent in the ministry's role as both the regulator and the promoter of the financial services sector (Hartcher, 1998). In 2000, the Financial Services Authority was established as the unified supervisor. On balance, the new agency is less independent than its predecessor(s), although commentators on Japan have praised the agency for its more decisive handling of the banking system.

- $\quad$ The Financial Supervisory Commission (FSC) in Korea was established in April 1998 and the Financial Supervisory Service (FSS) in January 1999. The former was created to act as an integrated supervisory agency for all types of financial institutions and markets, while the latter was established to function as its executive arm. The FSC is a state agency (whereas FSS has been established as a private corporation), which is reflected in the relatively low independence and accountability ratings. Kim and others (2002) comment that the new regulatory regime in effect turned into a hierarchical system headed by MOFE, among others, because MOFE retained the sole power to initiate legislation and regulations.

- $\quad$ The Chinese government moved banking supervision out of the central bank, the People's Bank of China ( $\mathrm{PBoC}$ ), into a separate agency to create a powerful voice among the government institutions in favor of maintaining the state-owned commercial banks' prudential soundness after their recapitalization. However, just like the People's Bank of China, the China Banking Regulatory Commission (CBRC) remains subject to the constitutional ruling that the state council is the supreme authority in the country. According to our rating system, this ruling allows no real independence of the supervisory authority. However, in line with the state objective, the new separate agency received some powers and voice not given earlier to the People's Bank, as can be seen in the ratings.

\section{F. Additional Perspectives}

Table 5 provides a regional perspective on the trends. It shows that arrangements in European countries are slightly better than in other parts of the world, both with respect to independence and accountability. European countries have made the greatest strides in terms of independence, with more limited progress in other regions. The African countries in the sample (Mauritius, South Africa, and Uganda) all established a regulator for nonbank financial institutions outside the central bank, while leaving the responsibility for bank supervision inside the central bank. Meanwhile, central bank legislation was revised, giving more attention to accountability in all three cases. The degree of accountability has 
progressed more or less equally in all parts of the world, with Europe maintaining the highest scores.

Table 5. Accountability and Independence: Regional Trends

(Average Rating)

\begin{tabular}{|c|c|c|c|c|}
\hline Af & rica & Europe & WHD & Asia-Pacific \\
\hline \multicolumn{5}{|l|}{ Total rating } \\
\hline Before & 414947 & & & 39 \\
\hline After & 566863 & & & 59 \\
\hline \multicolumn{5}{|c|}{ Independence } \\
\hline Before & 555454 & & & 44 \\
\hline After & 647168 & & & 60 \\
\hline \multicolumn{5}{|c|}{ Accountability } \\
\hline Before & 294341 & & & 35 \\
\hline After & 496558 & & & 57 \\
\hline
\end{tabular}

The picture emerging from Table 6 (a classification according to income levels) shows that the high-income countries score best in terms of accountability. This is due to the fact that arrangements like consultation with consumer representatives are more recognized as an issue to be addressed in high-income countries and mature democracies. On the other hand, the strengthening of the accountability arrangements is fairly evenly distributed among income groups. Middle-income countries score highest on independence arrangements, but the gap between the independence and accountability scores has remained wide.

Table 6. Accountability and Independence: Trends by Country Income Levels (Average rating)

\begin{tabular}{|c|c|c|c|}
\hline & High Income & Middle Income & Low Income \\
\hline \multicolumn{4}{|l|}{ Total rating } \\
\hline Before 50 & & 45 & 38 \\
\hline After 66 & & 65 & 57 \\
\hline \multicolumn{4}{|l|}{ Independence } \\
\hline Before 55 & & 54 & 44 \\
\hline After 68 & & 73 & 61 \\
\hline \multicolumn{4}{|c|}{ Accountability } \\
\hline Before 45 & & 37 & 33 \\
\hline After 65 & & 58 & 54 \\
\hline
\end{tabular}


A comparison based on the institutional frameworks yields interesting observations. Table 7 groups the countries according to the location of banking supervision after the reforms. Some supervisory agencies stayed in the central bank, others moved out of the central bank and were merged with other sectoral supervisors, and yet others were already out of the central bank and were merged with other sectoral supervisors. Table 7 distinguishes between those agencies that are in the central bank and those that are outside the central bank, with a subcategory of the latter being the unified supervisors.

Table 7. Accountability and Independence: Trends by Location of Institution (Average rating)

\begin{tabular}{|c|c|c|c|}
\hline & $\begin{array}{c}\text { Inside Central } \\
\text { Bank }\end{array}$ & $\begin{array}{c}\text { Outside Central } \\
\text { Bank } \\
\end{array}$ & $\begin{array}{c}\text { Of Which Unified } \\
\text { Supervision }\end{array}$ \\
\hline \multicolumn{4}{|l|}{ Total rating } \\
\hline Before 46 & & 46 & 48 \\
\hline After 64 & & 64 & 65 \\
\hline \multicolumn{4}{|l|}{ Independence } \\
\hline Before 58 & & 51 & 52 \\
\hline After 73 & & 66 & 65 \\
\hline \multicolumn{4}{|l|}{ Accountability } \\
\hline Before 36 & & 41 & 44 \\
\hline After 56 & & 62 & 64 \\
\hline
\end{tabular}

This table provides evidence that strongly supports our earlier findings that (i) across agencies, supervisors in central banks remain more independent than their counterparts elsewhere, but their accountability arrangements are weaker; (ii) within categories of agencies, the gap between independence and accountability is wide for central banks, while arrangements for agencies outside central banks are more balanced (65-64 for unified supervisors), at the same time, these scores are not extremely high; and (iii) over time, the gap between independence and accountability arrangements for central banks hardly narrowed, while it did narrow for the other categories.

The trends observed here confirm that (i) there is reluctance among politicians to go all the way in granting independence to newly established supervisory agencies; and (ii) newly established agencies are endowed with more accountability arrangements than their central bank colleagues. Central bank accountability arrangements remain predominantly geared toward discharging the monetary policy responsibilities, a function which does not require the same types of arrangements that we suggest for supervisors. This concern seems to be only partly taken into account when the legal basis for supervisors housed in central banks was revised, but received more attention when a new agency was created. This finding supports the view that a thorough overhaul of the organizational structure provides more freedom to influence independence and accountability arrangements (confirmed in Table 8). 
Table 8. Accountability and Independence: Trends by Type of Change

(Average Rating)

\begin{tabular}{|c|c|c|}
\hline Leg & islative & $\begin{array}{c}\text { Institutional and } \\
\text { Legislative }\end{array}$ \\
\hline \multicolumn{3}{|l|}{ Total rating } \\
\hline Before 45 & & 47 \\
\hline After 62 & & 65 \\
\hline \multicolumn{3}{|l|}{ Independence } \\
\hline Before 53 & & 52 \\
\hline After 69 & & 67 \\
\hline \multicolumn{3}{|c|}{ Accountability } \\
\hline Before 37 & & 42 \\
\hline After 56 & & 64 \\
\hline
\end{tabular}

The trends also support earlier observations that some governments were frustrated with central banks that are not accountable in their view. They established more accountability mechanisms and, often, control mechanisms which, in the philosophy of our presentation of the ratings, reduced independence. The end-result is more balanced arrangements, but at a moderate rating level. Finally, the table can also be seen as supporting our view that many stakeholders still hold the trade-off view between independence and accountability: a great distance between both in the case of central banks, with independence at a relatively high level, and more balanced ratings in the others, but at lower levels.

Table 8 compares the results by type of reform-institutional changes versus purely legislative changes to existing agencies. This classification is only slightly different from the previous one because the heading "institutional reform" encompasses nearly all those countries that moved banking supervision outside the central bank ("outside central bank" in the previous table). This table confirms the findings in Table 7. Countries that underwent changes in the legal framework now have more independent supervisors, but had few far-reaching reforms in their accountability arrangements. Countries that organized institutional changes endowed the new agency with few independence features and more accountability arrangements. So, an institutional change was used —or invoked - to "correct" what was seen as an imbalance.

Finally, Table 9 considers the old saw that "it takes a crisis to reform." The table compares those countries that undertook (legislative and/or institutional) reforms in the wake of a crisis (eight countries) with those whose reforms were not related to a banking crisis. The survey does not strongly confirm the above saying. The only noticeable trend is that the crisis-countries had somewhat weaker arrangements before the reforms (particularly for independence) and they have subsequently caught up with countries that reformed without having experienced a crisis. Both groupings are now more or less at similar levels. The meaning of these findings is that other events/trends can apparently be sources as powerful for reform as crises. 
Table 9. Accountability and Independence: Trends by Immediate Cause of Reform (Financial Crisis or Not)

(Average)

\begin{tabular}{|c|c|c|}
\hline & $\begin{array}{c}\text { Reform } \\
\text { After Crisis }\end{array}$ & $\begin{array}{c}\text { Reform Not } \\
\text { Related to Crisis }\end{array}$ \\
\hline \multicolumn{3}{|l|}{ Total rating } \\
\hline Before 41 & & 48 \\
\hline After 66 & & 64 \\
\hline \multicolumn{3}{|l|}{ Independence } \\
\hline Before 44 & & 55 \\
\hline After 70 & & 68 \\
\hline \multicolumn{3}{|l|}{ Accountability } \\
\hline Before 39 & & 41 \\
\hline After 62 & & 60 \\
\hline
\end{tabular}

\section{Conclusions}

The main purpose of this paper has been to take stock of current developments with respect to independence and accountability for financial sector supervisors. Amidst the wave of reorganizations of supervisory structures around the world, more attention is being given to the governance structures of these institutions. This paper surveyed trends with respect to independence and accountability in a sample of 32 countries that restructured their supervisory landscape, or introduced legislative changes to the supervisory framework.

Compared with the case for central bank independence, which has won a broad following in both academic and policy circles (as is confirmed in recent work by Arnone, Laurens, and Segalotto (2006a and 2006b), the case for RSA independence remains more controversial. Policymakers have remained more reluctant to grant independence to regulators, despite strong arguments developed in its favor. Several reasons have been brought forward to explain this hesitation. They range from Stigler's regulatory capture theory (without political oversight, regulators will succumb to the industry's interests), over theories of political selfinterest, stating that politicians try to keep control over those activities (as opposed to delegating) that can generate rents, or have redistributive effects (Alesina and Tabellini, 2004), to genuine concerns that independence for RSAs is a delegation of authority too far. Such concerns often find their origin in a lack of understanding of the nature and operation of accountability arrangements.

Since many aspects of the RSA independence-accountability debate are still relatively newand it is worth noting that it took more than a decade before the idea of central bank independence as a monetary policy agent became widely accepted - the paper started off by putting the independence-accountability debate in the broader context of regulatory governance. Independence is not a goal in itself. It is one of the four essential pillars to 
support good governance in the RSA. Accountability is another pillar and serves to make independence effective. Good governance itself is necessary to instill good corporate governance in the supervised entities. Subsequently, the paper gave operational meaning to the notions of independence and accountability. We set out the four main dimensions of independence - institutional, regulatory, supervisory, and budgetary. For each of these four dimensions, we identified appropriate accountability arrangements.

Based on the operational elements of independence and accountability, the paper identified 19 criteria on independence and 21 on accountability to compose an index of independence and accountability. The legislation governing banking supervision agencies in the sample was tested against these 40 criteria. The test was done on the pre- and post-reform legislation, in order to identify the trends with respect to independence and accountability.

In general, the results are encouraging, but not unambiguously positive. The survey supports the view that RSA independence and accountability are slowly gaining acceptance - or, at least, are being considered seriously. The indices for both pillars of good governance increased markedly, which bodes well for the quality of regulatory governance. While the accountability ratings have improved more than the independence ratings, the latter remain on average higher. This "catching up" could be interpreted as a growing awareness of the importance of accountability. On the independence side, principles such as legal immunity for RSA staff, the right to issue prudential regulations, and budgetary autonomy are now more generally accepted than before. On the accountability side, frequent consultations with the legislative and executive branch are now a generalized practice, the right of supervised entities to appeal is commonly accepted, and the same applies to ex ante consultations with the supervised entities about regulatory policy matters. More generally, the widespread use of the internet has given transparency a boost, in support of accountability.

However, these positive results remain overshadowed by evidence that politicians remain doubtful, to put it mildly, about granting independence to RSAs. This lack of confidence is either translated into overcompensation on the accountability side or into the resort to direct control measures, or both. The general trends show that several countries now have an accountability index significantly above the independence index. Symptomatically, all the countries in this situation have a low degree of independence (50 or below). A detailed analysis reveals that the legislation in more than a third of the surveyed countries either allows for a minister or a ministerial representative on the decision-making board of the agency, or gives the minister the power to intervene in the agency's operations. The survey also showed that many governments wish to retain a role in the licensing and delicensing of banks, which they apparently still view as a politically very sensitive area. It is interestingor rather, puzzling - to note in this regard that there are instances where the law explicitly stipulates the agency's independence, and, at the same time, gives the minister the possibility to intervene in the agency's operations. 
These trends reveal at least two things. First, governments still see a trade-off between independence and accountability — as opposed to a relationship of mutual support — and that their revealed preference is for the latter, not the first. However, just because well-designed accountability arrangements might be used to support independence, it does not follow that stronger accountability without a corresponding "upgrading" of independence represents genuine progress or leads to better outcomes in terms of governance. Secondly, a large number of countries still tend to see "control" mechanisms as accountability mechanisms. While there is indeed a fine line between control and accountability, the trends discovered here show that not all governments are ready to let RSAs operate independently. These trends are best visible when one compares supervisors that remained in central banks with those that are being established outside the central banks. The latter are less independent by a significant margin. The trouble with introducing these control mechanisms is that they can potentially undermine the credibility of the agency and make genuine accountability arrangements irrelevant.

While the current trends prove that politicians experience a fear of "letting go," one must also admit that they are confronted with a fair portion of unfamiliarity with respect to the issues at stake. The combination of (i) the novelty of having to define a place for RSAs in the overall governance structure of the financial system; (ii) the fact that the drive for RSA independence and accountability is less than 10 years old; and (iii) the confrontation with the complexities inherent in financial sector supervision explains that policymakers are still struggling to work out "balanced" arrangements for RSAs, resulting in reluctance and trial and error, which are also visible in our results.

Indeed, the paper noted that developments are uneven and (new) arrangements are far from homogenous across countries, as is evidenced by wide disparities between independence and accountability indices in a large number of cases. Such disparities seem related to unfamiliarity with the operation of accountability and with the idea that accountability can be used to support independence, not necessarily to curtail it. Independence without corresponding accountability could potentially be dangerous and, at times of crisis, backfire on the RSA.

Another symptom of the unfamiliarity is the much greater variety of governance structures for RSAs than for central banks. In part, this variation may simply reflect the inherent complexity of designing accountability arrangements for RSAs, which therefore lend themselves to a variety of solutions, none of which are obviously superior to the others. In addition, unlike central banks, RSAs often find that they have a line of accountability to another agency - usually the central bank itself. These arrangements may reflect the (correct) perception that the central bank needs to be closely involved in financial supervision and regulation owing to its overarching financial stability remit. In this regard, the paper also notes that the design of accountability arrangements in central banks nearly exclusively reflects its monetary policy function. For those central banks that are also financial supervisors, there is a need to "upgrade" accountability mechanisms to reflect the complexity of this task. 
Taken together, the results point out that more work is needed on persuading policymakers of the long-term benefits of RSA independence; on understanding better the nature, purpose, and operation of accountability; and on explaining how well-designed accountability arrangements can be used to support independent agencies in the discharge of their remit. Only progress in these topics will help politicians to get rid of their lingering fear of freedom for RSAs. 


\section{APPENDIX I. COUNTRIES SELECTED FOR THE SURVEY}

\begin{tabular}{|c|c|c|c|c|}
\hline Country & Year of Reform & $\begin{array}{l}\text { Banking } \\
\text { Crisis } \\
\text { (Year) }\end{array}$ & $\begin{array}{c}\text { Location Bank } \\
\text { Supervision Before } \\
\text { Reforms }\end{array}$ & $\begin{array}{c}\text { Location Bank } \\
\text { Supervision After } \\
\text { Reforms }\end{array}$ \\
\hline Australia 1 & 998 & & $\mathrm{CB}$ & $\mathrm{OCB}, \mathrm{U}^{3 /}$ \\
\hline Austria 2 & 002 & & $\mathrm{MOF} / \mathrm{CB}^{1 /}$ & OCB, U \\
\hline Bahamas (The) & 2000 & & $\mathrm{CB}$ & $\mathrm{CB}$ \\
\hline Belgium 2 & 004 & & OCB & $\mathrm{OCB}, \mathrm{U}$ \\
\hline Canada 2 & 006 & & OCB & $\mathrm{OCB}, \mathrm{U}$ \\
\hline Chile 1 & 997 & & OCB & OCB \\
\hline China, PR & 2004 & $\begin{array}{l}\text { Distress } \\
\text { throughout } \\
\text { 1990s }\end{array}$ & CB OCB & \\
\hline Colombia 2 & $003 / 2005^{4 /}$ & & OCB & $\mathrm{OCB}, \mathrm{U}$ \\
\hline Denmark 19 & 88 & $\begin{array}{l}\text { Distress in } \\
\text { early } 1990 \text { s }\end{array}$ & MOI OCB, & $\mathrm{U}$ \\
\hline Ecuador 20 & 01 & 2000 & OCB & OCB \\
\hline Estonia 1 & 998 & & $\mathrm{CB}$ & OCB \\
\hline Finland 19 & $93 / 2003^{4 /}$ & $1991 \mathrm{MO}$ & $\mathrm{F}$ & $\mathrm{OCB}, \mathrm{U}^{2 /}$ \\
\hline Germany 2 & 002 & & $\mathrm{OCB} / \mathrm{CB}{ }^{1 /} \mathrm{OCB} / \mathrm{CB}$, & $\mathrm{U}^{1 /}$ \\
\hline Guatemala & 2002 & & $\mathrm{OCB}, \mathrm{U}$ & $\mathrm{OCB}, \mathrm{U}$ \\
\hline Hungary 2 & $000 / 2004^{4 /}$ & $\mathrm{OCB}$ & & $\mathrm{OCB}, \mathrm{U}$ \\
\hline Indonesia 2 & 004 & 1997 & $\mathrm{CB}$ & $\mathrm{CB}^{5 l}$ \\
\hline Ireland 2 & 003 & & $\mathrm{CB}$ & $\mathrm{CB}, \mathrm{U}$ \\
\hline Japan 2000 & & $\begin{array}{l}\text { Distress } \\
\text { throughout } \\
\text { 1990s }\end{array}$ & $\mathrm{MOF} / \mathrm{CB}^{1 /}$ & $\mathrm{OCB} / \mathrm{CB}^{1 /}$ \\
\hline Korea 1 & 997 & 1997 & $\mathrm{MOF} / \mathrm{CB}^{1 /}$ & OCB \\
\hline Latvia 2 & 001 & & $\mathrm{CB}$ & $\mathrm{OCB}, \mathrm{U}$ \\
\hline Mauritius 2 & 004 & & $\mathrm{CB}$ & $\mathrm{CB}$ \\
\hline Mexico 1 & 995 & 1994 & $\mathrm{OCB}$ & OCB \\
\hline Netherlands 2 & 004 & & $\mathrm{CB}$ & $\mathrm{CB}^{3 /}$ \\
\hline Nicaragua & 2004 & 2000 & $\mathrm{OCB}, \mathrm{U}$ & $\mathrm{OCB}, \mathrm{U}$ \\
\hline Norway 19 & $88 / 2003^{4 /} 1$ & 991 & $\mathrm{OCB}$ & $\mathrm{OCB}, \mathrm{U}$ \\
\hline Poland 1 & 997 & & $\mathrm{CB}$ & $\mathrm{CB}$ \\
\hline South Africa & 1991 & & $\mathrm{CB}$ & $\mathrm{CB}$ \\
\hline Sweden 19 & $91 / 2003^{4 /} 1$ & 991 & OCB & $\mathrm{OCB}, \mathrm{U}$ \\
\hline Trinidad and Tobago & 2005 & & $\mathrm{CB}$ & $\mathrm{CB}$ \\
\hline Turkey 2 & 001 & 2000 & $\mathrm{MOF} / \mathrm{CB}^{1 /}$ & OCB \\
\hline Uganda 2 & 004 & & $\mathrm{CB}$ & $\mathrm{CB}$ \\
\hline United Kingdom & 1997 & & $\mathrm{CB}$ & $\mathrm{OCB}, \mathrm{U}$ \\
\hline
\end{tabular}

Notes:

$\mathrm{CB}=$ in central bank; $\mathrm{OCB}=$ outside central bank; $\mathrm{U}=$ unified.

1/ Central bank in charge of on-site inspections.

2/ Affiliated with the central bank.

3/ Part of a "twin peak" arrangement.

4/ two reforms - last one is taking into account.

5/ bank supervision will be transferred to unified supervisor in 2010 . 


\section{APPENDIX II. CRITERIA FOR THE INDEX ON INDEPENDENCE AND ACCOUNTABILITY FOR FINANCIAL SECTOR SUPERVISORS}

\begin{tabular}{|c|c|c|c|c|}
\hline Criteria/Ratings & -1 & $\mathbf{0}$ & 1 & 2 \\
\hline \multicolumn{5}{|l|}{ Independence (19) } \\
\hline \multicolumn{5}{|l|}{ 1. Institutional Independence } \\
\hline Has the agency a legal basis (law, act, $\ldots$ ) & & No & & Yes \\
\hline $\begin{array}{l}\text { Does the law state that the institution is } \\
\text { independent }\end{array}$ & No & & & Yes \\
\hline $\begin{array}{l}\text { How are the chairman and senior executives } \\
\text { appointed? }\end{array}$ & B & $\begin{array}{l}\text { y government } \\
\text { (or other } \\
\text { procedure) }\end{array}$ & $\begin{array}{l}\text { By Head of state } \\
\text { upon proposal } \\
\text { of government }\end{array}$ & $\begin{array}{l}\text { By parliament } \\
\text { upon proposal } \\
\text { of government }\end{array}$ \\
\hline $\begin{array}{l}\text { Is the decision-making body a board or the } \\
\text { president (a single person) }\end{array}$ & Presid & ent only & & $\begin{array}{l}\text { Collegial } \\
\text { decision making }\end{array}$ \\
\hline $\begin{array}{l}\text { Who has legal immunity for actions done in } \\
\text { good faith? }\end{array}$ & & $\begin{array}{l}\text { No one in the } \\
\text { agency }\end{array}$ & $\begin{array}{l}\text { Senior } \\
\text { management } \\
\text { only }\end{array}$ & All staff \\
\hline $\begin{array}{l}\text { Are parliamentarians sitting on policy board of } \\
\text { agency }\end{array}$ & Yes & & & No \\
\hline $\begin{array}{l}\text { Is there a government official on the agency } \\
\text { policy board }\end{array}$ & Yes & & & No \\
\hline $\begin{array}{l}\text { Does the law/act give the minister of finance } \\
\text { oversight power? }\end{array}$ & Yes & & & No \\
\hline $\begin{array}{l}\text { Has the law defined clear criteria for dismissal } \\
\text { of the president of the agency? }\end{array}$ & & $\begin{array}{l}\text { No, there is } \\
\text { nothing in the } \\
\text { law }\end{array}$ & $\begin{array}{l}\text { There is } \\
\text { something, but } \\
\text { not specific }\end{array}$ & Yes \\
\hline \multicolumn{5}{|l|}{ 2. Regulatory Independence } \\
\hline $\begin{array}{l}\text { Can the agency autonomously issue legally } \\
\text { binding prudential regulations for the sector? }\end{array}$ & & No & $\begin{array}{l}\text { No, but it can } \\
\text { issue non } \\
\text { binding } \\
\text { guidelines, etc }\end{array}$ & Yes \\
\hline \multicolumn{5}{|l|}{ 3. Supervisory Independence } \\
\hline $\begin{array}{l}\text { Has the agency the (sole) right to issue } \\
\text { licenses? }\end{array}$ & No & right & $\begin{array}{l}\text { After } \\
\text { consultation } \\
\text { with } \\
\text { government or } \\
\text { other agency }\end{array}$ & Yes \\
\hline $\begin{array}{l}\text { Has the agency the (sole) right to withdraw } \\
\text { licenses? }\end{array}$ & No & right & $\begin{array}{l}\text { After } \\
\text { consultation } \\
\text { with } \\
\text { government or } \\
\text { other agency }\end{array}$ & Yes \\
\hline $\begin{array}{l}\text { Has the agency the sole right to impose } \\
\text { sanctions on supervised institutions? }\end{array}$ & No & & & Yes \\
\hline $\begin{array}{l}\text { Has the agency the right to enforce supervisory } \\
\text { sanctions? }\end{array}$ & No & & & Yes \\
\hline \multicolumn{5}{|l|}{ 4. Budgetary Independence } \\
\hline How is the agency funded? & & $\begin{array}{l}\text { From } \\
\text { government } \\
\text { budget only }\end{array}$ & $\begin{array}{l}\text { Mixed formula } \\
\text { involving } \\
\text { government } \\
\text { budget }\end{array}$ & $\begin{array}{l}\text { From fees, } \\
\text { through central } \\
\text { bank budget, or } \\
\text { mix of the two, } \\
\text { but no } \\
\text { government } \\
\text { funds }\end{array}$ \\
\hline
\end{tabular}




\begin{tabular}{|l|l|l|l|l|}
\hline \multicolumn{1}{|c|}{ Criteria/Ratings } & \multicolumn{1}{c|}{$-\mathbf{1}$} & \multicolumn{1}{c|}{$\mathbf{0}$} & \multicolumn{1}{c|}{$\mathbf{2}$} \\
\hline $\begin{array}{l}\text { Need the agency submit the budget to the } \\
\text { government for a priori approval (incl. for approval } \\
\text { of fee structure) }\end{array}$ & & Yes & $\begin{array}{l}\text { (Partial - for } \\
\text { instance fee } \\
\text { structure,...) }\end{array}$ & No \\
\hline $\begin{array}{l}\text { Has the agency the authority to define salaries and } \\
\text { salary structure of staff }\end{array}$ & No & & & Yes \\
\hline $\begin{array}{l}\text { Has the agency the authority to autonomously hire } \\
\text { staff }\end{array}$ & No & & & Yes \\
\hline $\begin{array}{l}\text { Has the agency the authority to define the internal } \\
\text { organizational structure? }\end{array}$ & No & & & Yes \\
\hline
\end{tabular}

\begin{tabular}{|c|c|c|c|c|}
\hline Criteria/Ratings & -1 & $\mathbf{0}$ & 1 & 2 \\
\hline \multicolumn{5}{|l|}{ Accountability (21 ) } \\
\hline \multicolumn{5}{|l|}{ 1. Mandate } \\
\hline $\begin{array}{l}\text { Is the agency's mandate defined in the enabling } \\
\text { legislation? }\end{array}$ & No & & & Yes \\
\hline \multicolumn{5}{|l|}{ 2. Accountability towards legislature } \\
\hline $\begin{array}{l}\text { Is there an obligation in the law to present annual } \\
\text { report to legislative branch }\end{array}$ & No & & & Yes \\
\hline $\begin{array}{l}\text { Does the law provide for possibility of regular } \\
\text { hearings before committees (quarterly, ...) }\end{array}$ & No & & & Yes \\
\hline $\begin{array}{l}\text { Is accountability to legislature delegated to finance } \\
\text { minister (i.e., not the chair of the agency presents } \\
\text { the report to parliament but the minister of finance). }\end{array}$ & Yes & $1 /$ & & No \\
\hline \multicolumn{5}{|l|}{ 3. Accountability to executive branch } \\
\hline $\begin{array}{l}\text { Is there an obligation in the law to present annual } \\
\text { report to executive branch }\end{array}$ & No & & & Yes \\
\hline $\begin{array}{l}\text { Does the law provide for a possibility of regular } \\
\text { briefing meetings with minister of finance } \\
\text { (quarterly, ...) }\end{array}$ & No & & & Yes \\
\hline $\begin{array}{l}\text { Does the law provide for the possibility for ad hoc } \\
\text { hearings }\end{array}$ & No & & & Yes \\
\hline \multicolumn{5}{|l|}{ 4. Accountability toward judiciary branch } \\
\hline $\begin{array}{l}\text { Have supervised entities the right to appeal } \\
\text { supervisory decision to courts? }\end{array}$ & No & & & Yes \\
\hline $\begin{array}{l}\text { Are there distinct judicial processes to handle these } \\
\text { appeals? }\end{array}$ & & No & & Yes \\
\hline $\begin{array}{l}\text { Are there specialized judges to handle these } \\
\text { appeals? }\end{array}$ & No & & & Yes \\
\hline Are there penalties for faulty supervision? & & No & & Yes \\
\hline \multicolumn{5}{|l|}{ 5. Budgetary accountability } \\
\hline $\begin{array}{l}\text { Is there a process whereby the agency presents and } \\
\text { discusses its budget ex post? }\end{array}$ & No & & & Yes \\
\hline \multicolumn{5}{|l|}{ 6. Transparency } \\
\hline $\begin{array}{l}\text { Is there disclosure of policies and of decisions? } \\
\text { (website?) }\end{array}$ & No & & & Yes \\
\hline Has the agency issued a mission statement? & & No & & Yes \\
\hline Is the annual report available to the general public & & No & & Yes \\
\hline $\begin{array}{l}\text { Is there possibility for inquiries by general public? } \\
\text { (email, ombudsman?) }\end{array}$ & No & & & Yes \\
\hline
\end{tabular}




\begin{tabular}{|l|l|l|l|l|}
\hline \multicolumn{1}{|c|}{ Criteria/Ratings } & $-\mathbf{1}$ & \multicolumn{1}{c|}{$\mathbf{0}$} & \multicolumn{1}{c|}{$\mathbf{2}$} \\
\hline Is there a consumer grievance board & & No & $\begin{array}{l}\text { Other } \\
\text { arrangement } \\
\text { (e.g., outside } \\
\text { supervisory } \\
\text { agency) }\end{array}$ & Yes \\
\hline 7. Other & & & & \\
\hline $\begin{array}{l}\text { Is there a formal ex ante consultation process with } \\
\text { the industry about new regulations? }\end{array}$ & No & & & Yes \\
\hline $\begin{array}{l}\text { Is there a formal consultation process with the } \\
\text { public at large about new regulations }\end{array}$ & No & & & Yes \\
\hline Is there an internal audit process? & & No & & Yes \\
\hline Is there an external audit process? & & No & & Yes \\
\hline
\end{tabular}

1/ This is the tradition in the Westminster style of government. 
APPENDix III. Scatter Plot of RATings Before AND After

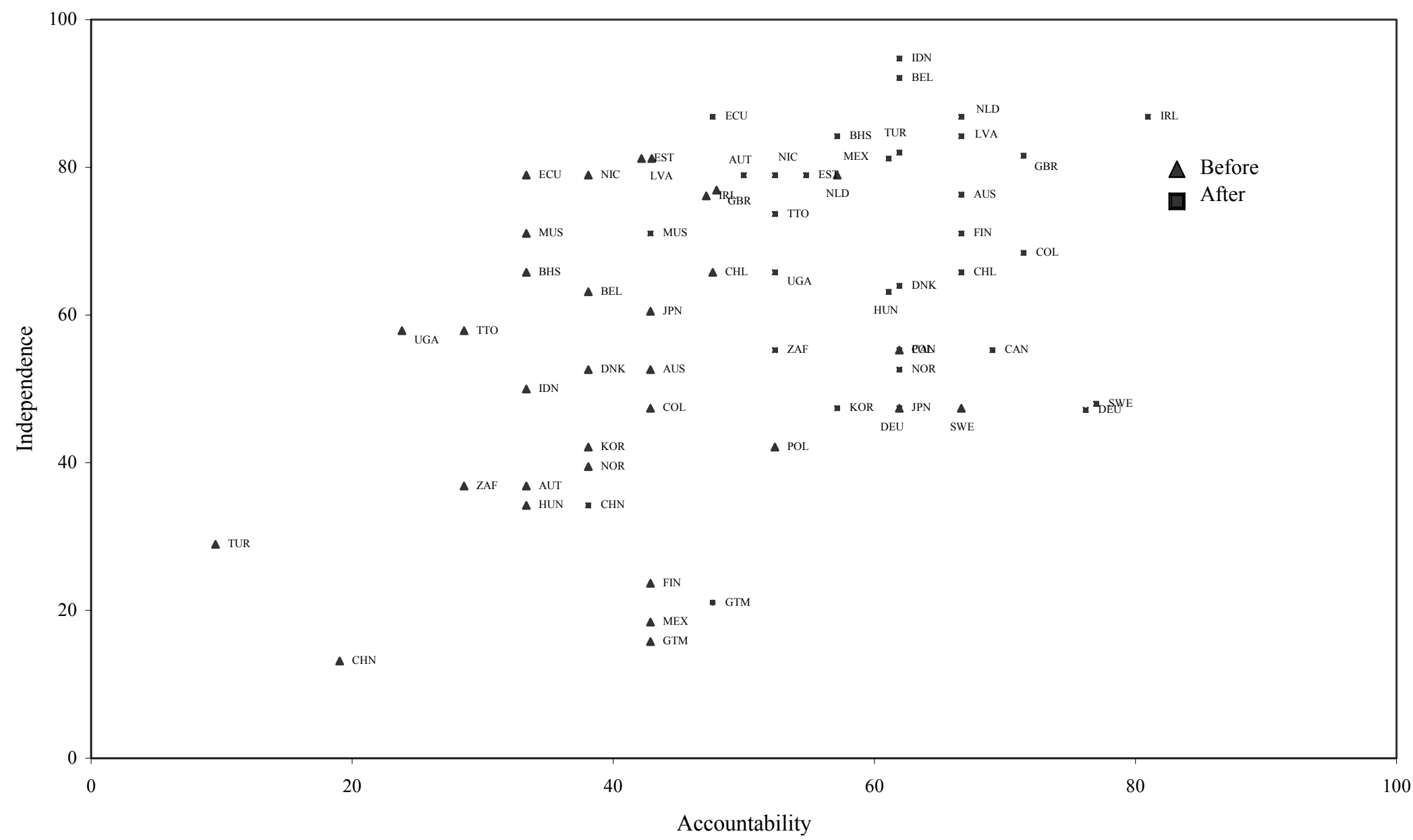




\section{APPENDix IV. Total RATING-Before AND AFTER}

(IN PERCENT OF BENCHMARK)
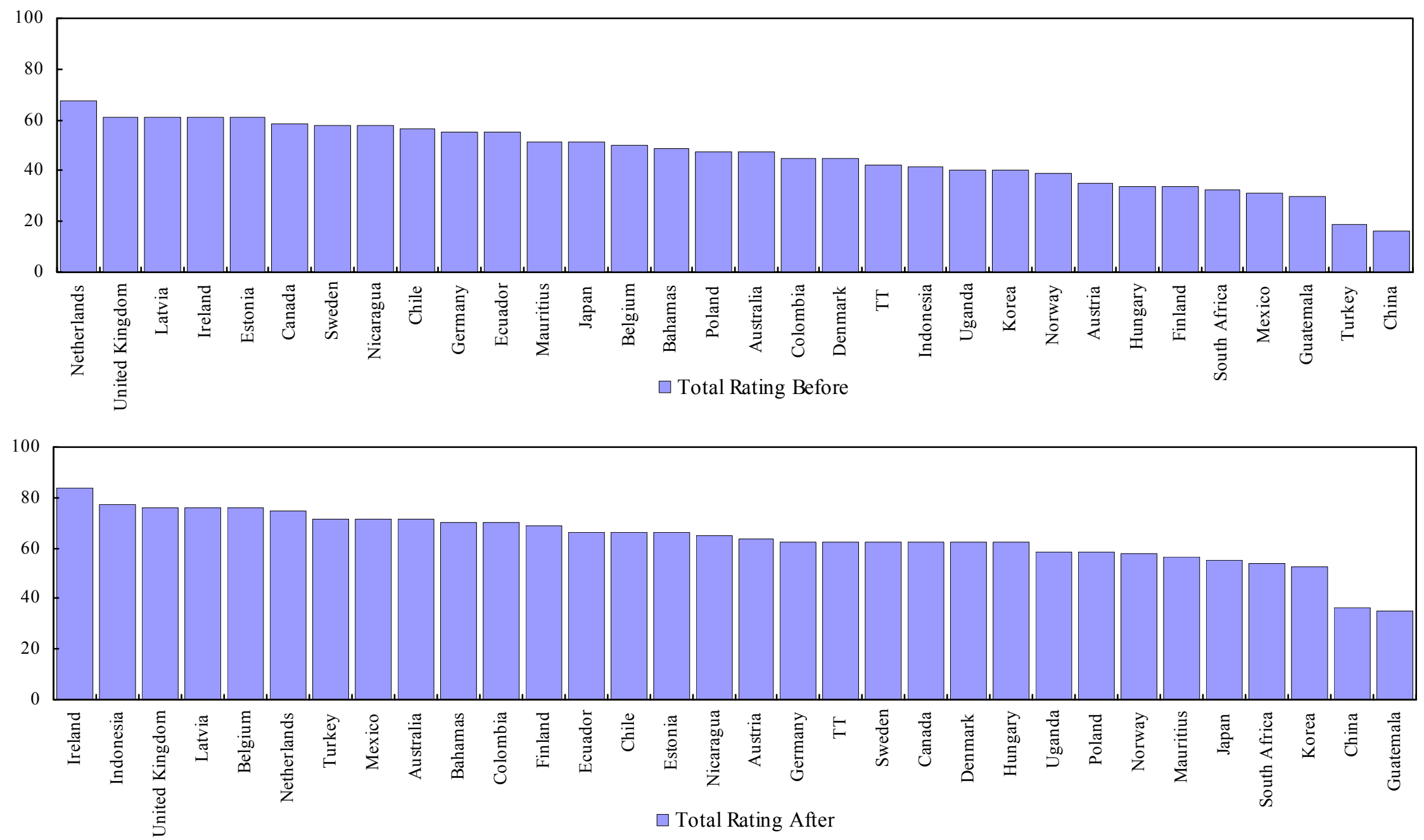


\section{APPENDIX V. INDEPENDENCE-BEFORE AND AFTER}

(IN PERCENT OF BENCHMARK)

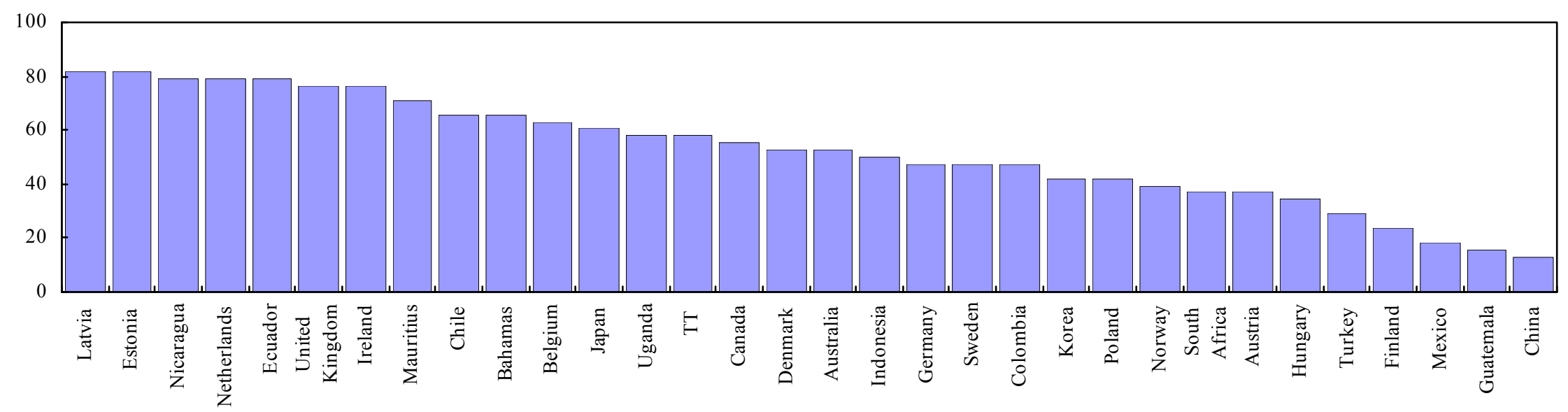

$\square$ Independence Before

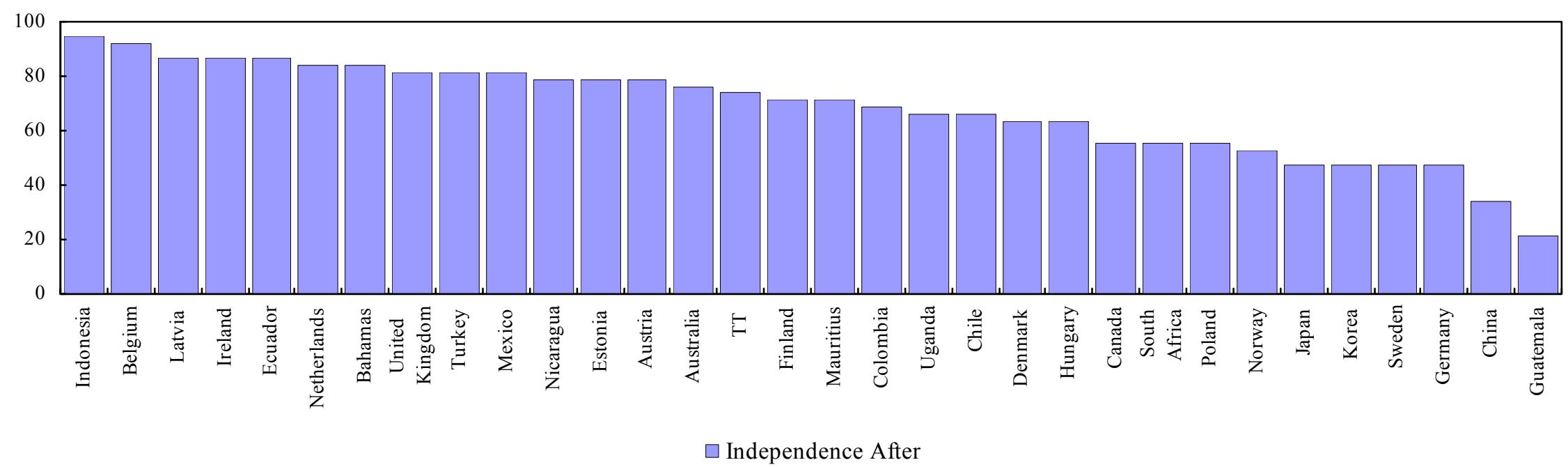


APPENDix VI. ACCOUNTABILITY-Before AND AfTER

(IN PERCENT OF BENCHMARK)

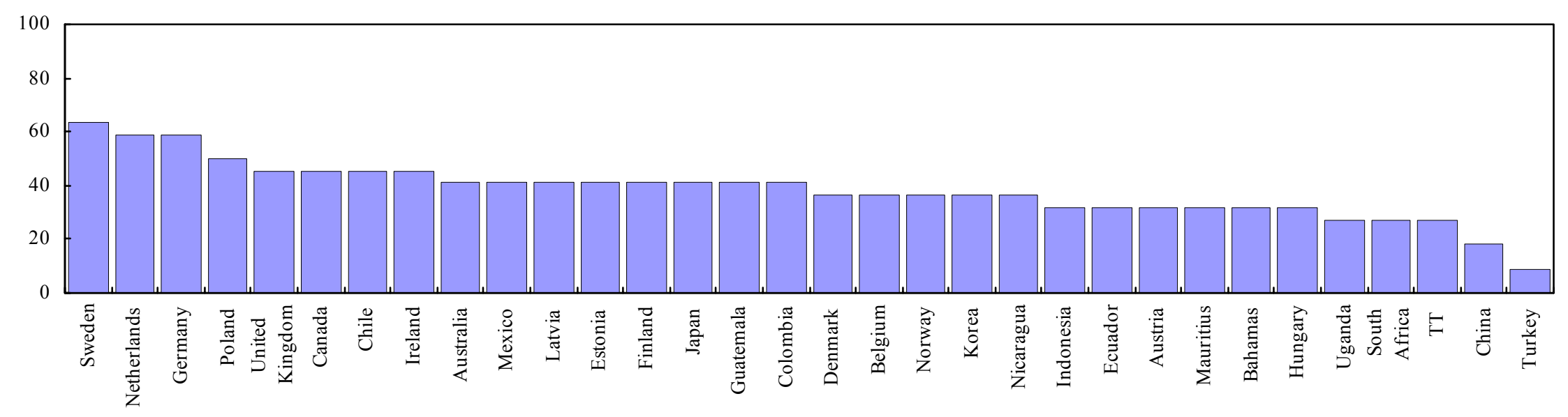

$\square$ Accountability Before

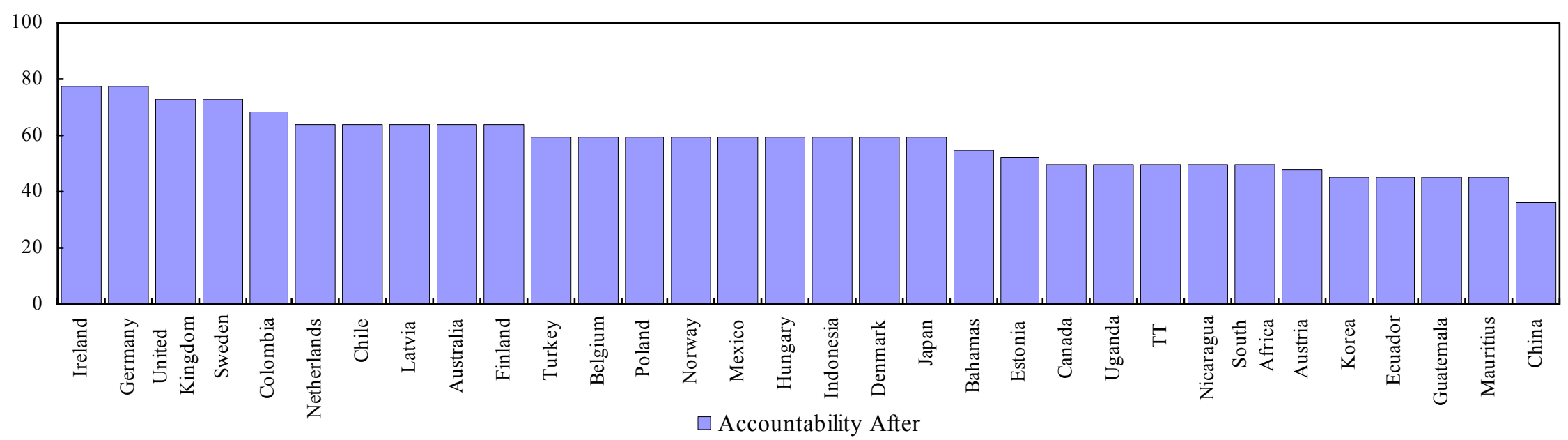




\section{REFERENCES}

Alesina, Alberto, and Guido Tabellini, 2004, "Bureaucrats or Politicians," NBER Working Paper No. 10241 (Cambridge, Massachusetts: National Bureau of Economic Research).

Amtenbrink, Fabian, 1999, The Democratic Accountability of Central Banks: A Comparative Study of the European Central Bank (Oxford and Portland: Hart Publishing).

Arnone, Marco, Salim Darbar, and Alessandro Gambini, forthcoming, "Public Sector Governance in Banking Supervision: Theory and Practices," IMF Working Papers (Washington: International Monetary Fund).

Arnone, Marco, Bernard Laurens, and Jean-François Segalotto, 2006a, "The Measurement of Central Bank Autonomy: Survey of Models, Indicators, and Empirical Evidence,’ IMF Working Paper 06/227(Washington: International Monetary Fund).

— $2006 \mathrm{~b}$, "Measures of Central Bank Autonomy: Empirical Evidence for OECD and Developing Countries, and Emerging Market Economies," IMF Working Paper 06/228 (Washington: International Monetary Fund).

Bade, Robert, and M. Parkin, 1977, "Central Bank Laws and Monetary Policy: A Preliminary Investigation,” (London, Ontario: University of Western Ontario).

Balogh, László, 2005, "Hungary," in Handbook of Central Banking and Financial Authorities in Europe: New Architectures in the Supervision of Financial Markets, ed. by Donato Masciandaro (Cheltenham, U.K.: Edward Elgar).

Barth, James, Gerard Caprio, and Ross Levine, 2001, "The Regulation and Supervision of Banks around the World: A New Database," in Brookings-Wharton Papers on Financial Services, ed. by Robert Litan and Richard Herring (Washington: Brookings Institution Press).

— , 2005, “Until Angels Govern” (Washington DC).

Basel Committee on Banking Supervision, 1997, "Core Principles for Effective Banking Supervision”(Basel: Bank for International Settlements).

Bezuidenhout, Andre, 2004, "The South African Case," in Aligning Financial Supervisory Structures with Country Needs, ed. by Jeffrey Carmichael, Alexander Fleming, and David Llewellyn (Washington: World Bank).

Carmichael, Jeffrey, 2004, “Australia's Approach to Regulatory Reform,” in Aligning Financial Supervisory Structures with Country Needs, ed. by J. Carmichael, A. Fleming, and D. Llewellyn (Washington: World Bank). 
Čihák, Martin, and Richard Podpiera, 2006, "Is One Watchdog Better Than Three? International Experience with Integrated Financial Sector Supervision," IMF Working Paper 06/57 (Washington: International Monetary Fund).

Commonwealth of Australia, 1996, "Financial System Inquiry Interim Report" (Wallis Commission) (Canberra: Australian Government Publishing Service).

Courtis, Neil, ed., 2005, How Countries Supervise Their Banks, Insurers, and Securities Markets (London: Central Banking Publications).

Cukierman, Alex, 1992, Central Bank Strategy, Credibility, and Autonomy (Cambridge, Massachusetts: MIT).

— Steven B. Webb, and Bilin Neyapti, 1992, "Measuring the Independence of Central Banks and its Effects on Policy Outcomes," World Bank Economic Review, Vol. 6 (September), pp. 353-98.

Das, Udaibir, and Marc Quintyn, 2002, "Financial Crisis Prevention and Crisis Management-The Role of Regulatory Governance," in Financial Sector Governance: The Roles of the Public and Private Sectors, ed. by Robert Litan, Michel Pomerleano, and V. Sundararajan (Washington: Brookings Institution Press).

Das, Udaibir, Marc Quintyn, and Kina Chenard, 2004, "Does Regulatory Governance Matter for Financial System Stability? An Empirical Analysis," in Bank of Canada, The Evolving Financial System and Public Policy, proceedings of a conference held by the Bank of Canada, Ottawa, December 2003.

Davis, Howard, 2004, "Integrated Regulation in the United Kingdom and the Lessons for Others" in Aligning Financial Supervisory Structures with Country Needs, ed. by Jeffrey Carmichael, Alexander Fleming, and David Llewellyn (Washington: World Bank).

de Krivoy, Ruth, 2000, Collapse: The Venezuelan Banking Crisis of 1994 (Washington: Group of Thirty).

de Haan Jakob, Fabian Amtenbrink, and Sylvester Eijffinger, 1999, "Accountability of Central Banks: Aspects and Quantification," Banca Nazionale del Lavoro Quarterly Review, No. 209 (June), pp. 167-93.

De Luna Martinez, Jose, and T. Rose, 2003, "International Survey of Integrated Supervision," in Financial Regulation: A Guide to Structural Reform, ed. by Douglas Arner and Jan-juy Lin (Hong Kong: Thomson Sweet and Maxwell Asia).

Eijffinger, Sylvester, and Petria Geraarts, 2004, "How Transparent are Central Banks?" University of Cambridge Working Papers in Economics No. 0410 (Cambridge: Cambridge University Press). 
Fischer, Stanley, 1994, "Modern Central Banking," in The Future of Central Banking: The Tercentenary Symposium of the Bank of England, ed. by Forrest Capie and others (Cambridge: Cambridge University Press).

Goodhart, Charles, 2001, "Regulating the Regulators-Accountability and Control," in Regulating Financial Services and Markets in the $21^{\text {st }}$ Century, ed. by Ellis Ferran and Charles Goodhart (Oxford: Hart Publishing).

_ 2002, "The Organization Structure of Banking Supervision," Economic Notes by Banca Monte dei Paschi di Siena, Vol. 31, No. 1, pp. 1-32.

— ed. 1998, "The Emerging Framework of Financial Regulation," a collection of papers compiled by the Financial Markets Group of the London School of Economics (London: Central Banking Publications Ltd.).

Goodhart, Charles, and others, 1998, Financial Regulation: Why, How and Where Now? (London and New York: Routledge).

Graham, Cosmo, 1998, "Is There a Crisis in Regulatory Accountability," in A Reader in Regulation, ed. by R. Baldwin, C. Scott, and C. Hood (Oxford: Oxford University Press), pp. 482-522.

Grilli, Vittorio, Donato Masciandaro, and Guido Tabellini, 1991, "Political and Monetary Institutions and Public Financial Policies in the Industrial Countries," Economic Policy, Vol. 13 (October), pp. 341-92.

Grünbichler, Andreas, 2005, "Austria," in Handbook of Central Banking and Financial Authorities in Europe: New Architectures in the Supervision of Financial Markets, ed. by Donato Masciandaro (Cheltenham, U.K.: Edward Elgar).

Hartcher, Peter, 1998, The Ministry: How Japan's Most Powerful Institution Endangers World Markets (Boston: Harvard Business School Press).

Hoelscher, David, and Marc Quintyn, 2003, Managing Systemic Banking Crises, IMF Occasional Paper No. 224 (Washington: International Monetary Fund).

House of Commons Select Committee on Treasury, 1998, Accountability of the Bank of England, First Report from the Select Committee on Treasury, Session 1997-98, HC 282.

Hüpkes, Eva H.G., 2000, The Legal Aspects of Bank Insolvency (The Hague: Kluwer Law International). 
Hüpkes, Eva H.G., Marc Quintyn, and Michael Taylor, 2005a, "Regulatory Accountability: Do's and Don'ts," The Financial Regulator, Vol. 10 (June), pp. 23-30.

_, 2005b, "The Accountability of Financial Sector Supervisors: Theory and Practice," European Business Law Review, Vol 16, No 6, pp. 1575-1620.

Institute of International Bankers, various years, Global Survey, (New York).

International Monetary Fund and World Bank, 2002, "Implementation of the Basel Core Principles for Effective Banking Supervision: Experiences, Influences and Perspectives," IMF and World Bank Background Paper (Washington).

Kim, Daesik, and others, 2002, "Suggestions to Improve Deposit Insurance System in Korea" (December) (unpublished; Korea Money and Finance Association).

Kim, Hong-Bum, and Chung Lee, 2004, "Financial Reform and Supervisory Failure: A Critical Appraisal of Post-Crisis Reform in Korea," Working Paper 2004-02, Korea Development Institute.

— , 2005, "Financial Reform, Institutional Interdependence and Supervisory Failure in the Post-Crisis Korea," paper presented at the 2005 KDI/KAEA Conference on Korea's Corporate Environment and Sustainable Development Strategy. Seoul, July.

Kremers, Jeroen, Dirk Schoenmaker, and Peter Wierts, 2003, "Cross-Sector Supervision: Which Model?" in Brookings-Wharton Papers on Financial Services, ed. by Robert Litan and Richard Herring (Washington: Brookings Institution Press).

Lastra, Rosa Maria, 1996, Central Banking and Banking Regulation (London: LSE, Financial Markets Group).

— 2001, "How Much Accountability for Central Banks and Supervisors?" Central Banking, Vol. XII (November), pp. 69-75.

Lybek, Tonny, 1998, "Elements of Central Bank Autonomy and Accountability," MAE Operational Paper OP/98/1 (Washington: International Monetary Fund).

Majone, Giandomenico, 1993, "Controlling Regulatory Bureaucracies: Lessons from the American Experience,” European University Institute Working Papers No. 93/03 (Florence: European University Institute).

,- 1994 , "Independence vs. Accountability? Non-Majoritarian Institutions and Democratic Government in Europe," European University Institute Working Paper No. 94/03 (Florence: European University Institute).

Moe, Terry, 1987, "Interests, Institutions, and Positive Theory: the Politics of the NLRB," Studies in American Political Development, Vol. 2, pp. 236-99. 
Organization for Economic Cooperation and Development, 2005, "Designing Independent and Accountable Regulatory Agencies for High Quality Regulation," Proceedings of an expert meeting in London, January.

O’Neil Brown, Craig, and Serdar Dinc, 2004, "The Politics of Bank Failures: Evidence From Emerging Markets" (drafts; Ann Arbor: University of Michigan Business School).

Oosterloo, Sander, and Jakob de Haan, 2003, A Survey of Institutional Frameworks for Financial Stability, De Nederlandsche Bank Occasional Studies, Vol. I, No. 4.

— , 2004, "Central Banks and Financial Stability: A Survey," Journal of Financial Stability, Vol 1 (September), pp. 257-73.

Page, Alan, 2001, "Regulating the Regulator-A Lawyer's Perspective on Accountability and Control" in Regulating Financial Services and Markets in the $21^{\text {st }}$ Century, ed. by Ellis Ferran and Charles Goodhart (Oxford: Hart Publishing).

Quintyn, Marc, and M. Taylor, 2003, "Regulatory and Supervisory Independence and Financial Stability,” CESifo, Economic Studies, Vol. 49, No. 2, pp. 259-94.

Schüler, Martin, 2005, "Germany," in Handbook of Central Banking and Financial Authorities in Europe: New Architectures in the Supervision of Financial Markets, ed. by Donato Masciandaro (Cheltenham, U.K.: Edward Elgar).

Taylor, Michael, 1995, Twin Peaks: A Regulatory Structure for the New Century (London: Centre for the Study of Financial Innovation).

— 1996, Peak Practice (London: Centre for the Study of Financial Innovation).

Westrup, Jonathan, 2002, Financial Services Regulation in Ireland - the Accountability Dimension, Studies in Public Policy, No. 10 (Dublin: The Policy Institute).

_ 2005, "Ireland," in Handbook of Central Banking and Financial Authorities in Europe: New Architectures in the Supervision of Financial Markets, ed. by Donato Masciandaro (Cheltenham, U.K.: Edward Elgar).

, forthcoming, "Independence and Accountability: Why Politics Matter," in Designing Financial Supervision Institutions: Independence, Accountability, and Governance, ed. by Donato Masciandaro and Marc Quintyn (forthcoming; Cheltenham, U.K.: Edward Elgar). 